\title{
Value Chain Transition in East Asian Production Network
}

\author{
Shih-Mo Lin*, Hong Linh Dinh**
}

\begin{abstract}
This paper applies the decomposition method proposed by Wang et al. (2013), together with the multi-national input-output tables from World Input-Output Database (WIOD) to estimate the value-chain transition in East Asian production network. Specifically, we calculate and examine the domestic value-added absorbed abroad, foreign value-added embodied in country's gross exports, and vertical specialization measures to explore the relative positions of major East Asian countries in the global production chain over the period of 1995-2011. The analyses are at country-aggregate, country-sector, bilateral-aggregate and bilateral-sector levels. Based on our results, we answer the important question of whether Taiwan and South Korea have used China's production chains as an intermediary to re-export their products to other countries in the world. Furthermore, we answer the question that over the 1995-2011 periods, have Taiwan and South Korea exploited cheap labor from China to add value to their products before re-exported them to the rest of the world?
\end{abstract}

Keywords: Value chain, East Asia, WIOD, production network.

\footnotetext{
* Professor, Department of International Business and Director, Center for Applied Economic Modeling, Chung Yuan Christian University, Taiwan.

** Lecturer, Thai Nguyen University of Economics and Business Administration, Vietnam.
} 


\section{Introduction}

The strengthening economic ties among East Asian countries have given rise to increasing production fragmentation in the region. Due to these countries' geographical proximity to each other, and the declining costs of international communication and coordination, the opportunities for regional multi-stage production have been increasing. As a consequence, vertical specialization has become prevalent in the region's production networks, where production is fragmented into several sequential stages and these sequential stages can be distributed either within a country or across multiple countries.

Past literature looks at a country's domestic value-added as a measure of its contribution to the final product's value. This is the value spent on the different factors of production in said country before the products are exported, as opposed to the value of gross trade. To calculate a country's domestic value-added, imported inputs used in the production of exports have to be deducted from the value of gross exports. ${ }^{1)}$ The domestic value-added measured by the case study approach on international supply chains examines micro-level data on individual products instead of macro-level data. This approach, however, does not reflect the linkages between economies in the production of intermediate inputs before they are assembled as final goods. Moreover, the value of a particular good cannot accurately represent a country or even a country-sector's participation in international production networks. In addition, this method does not take into account the change in factor contents when production chains expand over time.

The works of Athukorala (2003), Masahisa et al. (2008), and Pula and Peltonen (2009), among others, find that since the early 1990s, the rise of production fragmentation has been the main driver of the region's economic growth. However, analyses on East Asia's production networks so far are conducted mainly from a macro perspective and are based on gross trade data. For example, Athukorala and Yamashita (2006) study production fragmentation in a global context and conclude that the dependence on international specialization in parts and components trade is proportionally larger in East Asia than in North America or Europe. Ando (2006) decomposes East Asian countries' machinery trade statistics into one-way trade, and horizontal and vertical intra-industry trade. He finds that the increase in trade of machinery parts and components is largely due to the expansion of back-and-forth transactions in vertically fragmented cross-border production processes.

1) For example, Apple's 30GB iPod is assembled in China and then exported to other countries. Trade statistics valued China's exports for this product at around \$US150 per unit in 2006. However, China's contribution to this value, or China's domestic value-added, was only \$US4 per unit. The remaining value-added comes from the United States, Japan, Taiwan, and other countries (Linden et al., 2007; and Varian, 2007). 
Standard gross trade statistics recorded in gross terms which include both intermediate inputs and final products, and "double count" the value of intermediate inputs that are imported. Wang et al. (2009) summarize three major shortcomings in the existing literature on production chains in East Asia based on gross trade data. First, in the presence of vertical specialization, gross trade statistics double count goods if they cross multiple national borders before being embodied in the final goods.2) Second, according to Hummels et al. (2001), analyses based on intermediate goods or parts- and componentstrade have to rely on rather arbitrary classifications of goods into final and intermediates. The final and most important shortcoming is that they are not able to identify the countries that are the real sources of value-added, nor quantify the contribution of each country to the total product value created in the production chains.

The aforementioned shortcomings can be overcome if we use data from national income accounts, which record domestic output in value-added terms. This method allows us to understand international multi-stage production as a system of value-added sources and destinations. In each stage, the producer purchases inputs from both domestic and foreign sources, and then adds value before re-exporting the products to the next stage of production or to final demand. Going further, a country's linkage to the East Asian production chains is considered strong when it imports foreign value-added extensively from this region, and when said country uses the imported value-added to produce more intermediate exports than final goods. Additionally, we can say that the linkage is strong when the country supplies its domestic value-added to the East Asian production networks predominantly as intermediates rather than as final goods. The distribution of a country's factor contents also determines its relative contribution to international production networks.

Koopman et al. (2012) propose a unified framework for gross exports accounting by integrating the literature on vertical specialization and on trade in value-added. This method breaks up a country's gross exports into various value-added components by source and identifies double counted terms.3) By showing which parts of gross trade statistics are double counted, and the sources of double counting, this framework connects official trade statistics (in gross value terms) and national accounting statistics (in value-added terms). Wang et al. (2013) further develop a framework to measure trade flows at the sector, bilateral, and bilateral sector level. Wang et al. decomposes bilateral sector level gross trade

2) Therefore it does not provide an accurate measure of trade, specifically with regard to the relative importance of specific trading regions and the technological sophistication of a country's exports (Athukolara, 2003).

3) "Double counted" terms are terms that have already been counted in a country's gross exports. Thus, if a given country exports a product that contains imported components, the imported components are considered "double counted" in the country's gross exports. 
flows into various value-added and double counted terms. Their framework more precisely reflects the sources of foreign value-added embodied in a country's gross exports and how this foreign value-added is used in said country's export production. They redefine the new value-added exports (VAX) ratio based on backward linkages, which not only accurately measures a country's domestic value-added exports but also shows the destination of these domestic value-added exports.

This paper aims to evaluate the value chain transition in East Asian production networks. We estimate the new Revealed Comparative Advantage (RCA) within the Electrical and Optical Equipment industry proposed by Wang et al. (2013). Wang et al. take into account both domestic and international production sharing to develop a new measure of a country-sector's RCA. This new RCA index is more reliable in measuring how a country-sector's comparative advantage compares to the same sector of other countries in the region. Using time series data also allows us to analyze the development of each country-sector's comparative advantage over time.

We also analyze Taiwan and South Korea's cooperation and competition with each other. To analyze their production cooperation, we ask the question "How much do Taiwan and South Korea contribute to each other's domestic and export production?" or "How much do they outsource to each other?" And these questions are answered by looking at the changes in the structure of these two economies' bilateral value-added trade over time. To evaluate their competition, we analyze these two economies' individual trade relationships with China, and answer the question: "How much of Taiwan and South Korea's domestic value-added is absorbed by China's domestic and export production?" The country that has a greater contribution to China's production would have more comparative advantage over the other.

The rest of the paper is organized as follows. Section 2 reviews some earlier works dealing with East Asian production networks. Section 3 describes the method and data used for empirical analysis. Section 4 explains our results and discusses the possible policy implications behind them. Section 5 concludes.

\section{Vertical Specialization and Value chains in East Asian production networks}

Hummels et al. (2001) measure a country's participation in vertical specialization (VS) as the amount of exported goods that are in turn used as intermediate goods in another country's production of goods for exports. By using the OECD input-output database and data from Mexico's maquiladoras, they estimate that these countries' level of participation 
in VS for the year 1990 was up by 30 percent from 1970. Also, the growth in VS exports accounts for 30 percent or more of the growth in overall exports between 1970 and 1990 . Hummels et al. indicate that the dramatic growth in cross-border specialization is because goods repeatedly encounter trade barriers as they cross borders multiple times, so even small decreases in tariffs and transport cost can lead to a significant increase in cross-border specialization.

Koopman et al. (2008a), however, argue that Hummels et al.'s approach is not appropriate for countries that engage in a lot of processing exports such as China, Mexico, and Vietnam. They then develop a general formula for computing domestic and foreign contents to be used in cases of pervasive exports processing. Because some of the input-output coefficients called for by Koopman et al.'s new formula are not generally available from conventional input-output tables, they propose a mathematical method to estimate these coefficients by combining information from trade statistics (which separate processing and normal trade) with standard input-output tables. Their estimation indicates that the share of foreign content in China's exports is about 50 percent, almost twice as high as the estimate from Hummels et al.'s formula. Foreign-invested firms also tend to have higher foreign content in their exports than Chinese firms.

Following Hummels et al., Johnson and Noguera (2012a) combine input-output and bilateral trade data to compute the value-added content of bilateral trade. They measure vertical specialization by calculating the ratio of value-added to gross exports (called VAX ratio) and set up a global input-output framework in five sectors: agriculture, hunting, forestry and fishing; natural resources; non-manufacturing industrial production; manufacturing; and services. Their results reveal that VAX ratio varies substantially across countries and sectors. VAX ratio is also computed from bilateral data. At this level, they find that VAX ratios differ widely across partners for individual countries. The reason for the difference of VAX ratios between pairs of bilateral trade partners is due to back-and-forth production sharing, which implies that value-added trade is scaled down relative to gross trade. Another reason is that multilateral production sharing gives rise to indirect trade, which occurs when countries process intermediate goods. ${ }^{4}$ )

Koopman et al. (2010) further create a systematic framework for decomposing a country's gross exports into domestic value-added exports, domestic value-added initially exported then returned home, and foreign content in exports. This framework integrates all previous measures of vertical specialization and value-added trade in the literature. In addition, it estimates at which stage double counted terms enter a country' exports statistics. Koopman et al. (2012) update the framework by identifying which parts of the official trade

4) Their results even show that for some country pairs, bilateral VAX ratios are larger than one, as bilateral value-added exports exceed gross exports. 
data are double counted, and also identifying the sources of the double counting.5) Their work is useful in bridging official trade (in gross value terms) and national accounts statistics (in value-added terms). Later, Wang et al. (2013) generalize the gross exports accounting framework to one that decomposes gross trade flows (for both exports and imports) at the sector, bilateral, or bilateral-sector level.

There have also been a large number of literatures on the vertical specialization in East Asia. For instance, Ando (2006) employs the decomposition-type threshold method to examine developments in East Asia's trade structure in the 1990s, particularly distinguishing among types of intra-industry trade (IIT). He confirms that vertical international production sharing in the machinery sector has become an essential part of each economy in East Asia in the 1990s. He finds that the significance of vertical IIT increases sharply while the relative importance of one-way trade declines. In addition, horizontal IIT is rare and the drastic increase in vertical IIT is largely due to the expansion of back-and-forth transactions in vertically fragmented production processes, rather than trade of quality-differentiated commodities.

Athukorala and Yamashita (2006) also show that international production fragmentation, which is the cross-border dispersion of component production within vertically integrated production processes, is an important feature of the deepening structural interdependence of the world economy. Pula and Peltonen (2009) use the 2006 Asian Input-Output table to analyze the dependence of emerging Asia's value-added through trade and production linkages on intraregional demand, and on demand from the advanced economies. Their results suggest that the business cycle dynamics in emerging Asia have recently become less sensitive to the global demand trends. The World Trade Organization (WTO) and the Institute of Developing Economies - Japan (IDE-JETRO) (2011) offer a more in-depth analysis of the diversity and complementarity of the Asian regional production system. Using a set of Asian input-output tables, the analysis reveals a dialectical relationship, characterized by significant structural diversity on the one hand, and a high degree of complementarity on the other one. This complementarity among Asian industries is both a cause for and a consequence of deepened economic interdependency between countries. After 2000, the emergence of China altered the regional network, and by 2005 , the network's center of gravity had clearly shifted there. The competitiveness of Chinese exports is not only attributable to its low production costs, but also to the complex intermediate goods imported from other countries, be they from Asia or the rest of the world.

5) This paper was recently published by the American Economic Reviews as: Koopman, R., Z. Wang, and S.-J. Wei, 2014."Tracing Value-Added and Double Counting in Gross Exports".American Economic Review, 104(2), pp. 459-94. 


\section{Methods and Data}

\subsection{Decomposition of gross exports}

World input-output model is employed to estimate the international production linkages, which requires a complete set of both intra- and inter-country data. This becomes workable with the appearance of inter-country input-output (ICIO) data flows. Table 1 below introduces the structure of this framework in the case of $\mathrm{G}$ countries and $\mathrm{N}$ sectors.

Table 1.

Inter-country flows of goods ( $\mathrm{G}$ countries and $\mathrm{N}$ sectors)

\begin{tabular}{|c|c|c|c|c|c|c|c|c|c|c|c|c|c|c|}
\hline \multirow{2}{*}{\multicolumn{2}{|c|}{ Selling sector }} & \multicolumn{9}{|c|}{ Purchasing Sector } & \multirow{2}{*}{\multicolumn{3}{|c|}{ Final Demand }} & \multirow{3}{*}{$\begin{array}{l}\text { Total } \\
\text { Output }\end{array}$} \\
\hline & & \multicolumn{4}{|c|}{ Country S } & $\cdots$ & \multicolumn{4}{|c|}{ Country G } & & & & \\
\hline Country & Sector & 1 & 2 & $\cdots$ & $n$ & & 1 & 2 & $\cdots$ & $n$ & $F^{s}$ & $\cdots$ & $F^{g}$ & \\
\hline \multirow{4}{*}{$\mathbf{S}$} & 1 & $z_{11}^{s s}$ & $z_{12}^{s s}$ & $\cdots$ & $z_{1 n}^{s s}$ & & $z_{11}^{s g}$ & $z_{12}^{s g}$ & $\cdots$ & $z_{1 n}^{s g}$ & $f_{1}^{s s}$ & $\cdots$ & $f_{1}^{s g}$ & $x_{1}^{s}$ \\
\hline & 2 & $z_{21}^{s s}$ & $z_{22}^{s s}$ & $\cdots$ & $z_{2 n}^{s s}$ & & $z_{21}^{s g}$ & $z_{22}^{s g}$ & $\cdots$ & $z_{2 n}^{s g}$ & $f_{2}^{s s}$ & $\cdots$ & $f_{2}^{s g}$ & $x_{2}^{g}$ \\
\hline & $\vdots$ & $\cdots$ & $\cdots$ & $\ldots$ & $\cdots$ & & $\cdots$ & $\cdots$ & $\ldots$ & $\cdots$ & & $\ldots$ & & $\vdots$ \\
\hline & $n$ & $z_{n 1}^{11}$ & $z_{n 2}^{11}$ & $\cdots$ & $z_{n n}^{11}$ & & $z_{n 1}^{s g}$ & $z_{n 2}^{s g}$ & $\cdots$ & $z_{n n}^{s g}$ & $f_{n}^{s s}$ & $\cdots$ & $f_{n}^{s g}$ & $x_{n}^{s}$ \\
\hline$\vdots$ & $\vdots$ & $\vdots$ & $\vdots$ & $\vdots$ & $\vdots$ & & $\vdots$ & $\vdots$ & $\vdots$ & $\vdots$ & $\vdots$ & & & $\vdots$ \\
\hline \multirow{4}{*}{$\mathbf{g}$} & 1 & $z_{11}^{g s}$ & $z_{12}^{g s}$ & $\cdots$ & $z_{1 n}^{g s}$ & & $z_{p p}^{g g}$ & $z_{p q}^{g g}$ & $\cdots$ & $z_{p n}^{g g}$ & $f_{1}^{g s}$ & $\cdots$ & $f_{1}^{g g}$ & $x_{1}^{g}$ \\
\hline & 2 & $z_{21}^{g s}$ & $z_{22}^{g s}$ & $\ldots$ & $z_{2 n}^{g s}$ & & $z_{21}^{g g}$ & $z_{22}^{g g}$ & $\cdots$ & $z_{2 n}^{g g}$ & $f_{2}^{g s}$ & $\cdots$ & $f_{2}^{g g}$ & $x_{2}^{g}$ \\
\hline & $\vdots$ & $\cdots$ & $\cdots$ & $\cdots$ & $\cdots$ & $\cdots$ & $\cdots$ & $\cdots$ & $\cdots$ & $\cdots$ & & $\cdots$ & & $\vdots$ \\
\hline & $n$ & $z_{n 1}^{g 1}$ & $z_{n 2}^{g s}$ & $\cdots$ & $z_{n n}^{g s}$ & & $z_{n 1}^{g g}$ & $z_{n 2}^{g g}$ & $\cdots$ & $z_{n n}^{g g}$ & $f_{n}^{g s}$ & $\cdots$ & $f_{n}^{g g}$ & $x_{n}^{g}$ \\
\hline \multicolumn{2}{|c|}{ Value-added } & $v a_{1}^{s}$ & $v a_{2}^{s}$ & $\cdots$ & $v a_{n}^{s}$ & & $v a_{1}^{g}$ & $v a_{2}^{g}$ & $\ldots$ & $v a_{n}^{g}$ & & & & \\
\hline \multicolumn{2}{|c|}{ Total Output } & $x_{1}^{s}$ & $x_{2}^{s}$ & $\cdots$ & $x_{n}^{s}$ & & $x_{1}^{g}$ & $x_{2}^{g}$ & $\cdots$ & $x_{n}^{g}$ & & & & \\
\hline
\end{tabular}

In Table $1, x_{1}^{s}$ is total output of sector 1 in country $s, v a_{1}^{s}$ is the direct value-added of sector 1 in country $s, f_{n}^{s g}$ is final goods produced by country $s$ 's sector 1 for final demand in country $g$, and $z_{11}^{s g}$ is intermediate goods produced in sector 1 in country $s$ and used for sector 1's production in country $g$. The other variables can be interpreted similarly. The direct input coefficients are generated by dividing the value of each sector's intermediate input by the total output of the same sector, such as $a_{11}^{s s}=z_{11}^{s s} / x_{1}^{s}$ and $a_{11}^{s g}=z_{11}^{s g} / x_{1}^{g} \cdot a_{11}^{s s}$ 
and $a_{11}^{s g}$ are interpreted as the dollars' worth of input from sector 1 per dollar's worth of this sector's output in country $s$, and the dollars' worth of input from sector 1 in country $s$ per dollar's worth of output of sector 1 in country $g$.

Based on the inter-country input-output table, Wang et al. (2013) developed an equation in which the gross exports of a country can be completely decomposed into the sum of sixteen terms, where every term has its own economic interpretation. In particular, for bilateral analysis, the framework can be regrouped as a 3-country case, in which $s$ is the source country, $r$ is $s$ ' major trade partner and $t$ the rest of the world. The sixteen terms are explained as follows.

The first term is domestic value-added embodied in the final goods exports of all sectors of Country $s$ to Country $r$. Each of them has two parts: domestic value-added created by the sector itself and domestic value-added created by the other sector embodied in the sector's final exports. The second term is domestic value-added embodied in Country $s$ ' sectors' intermediate exports that are used by Country $r$ to produce final goods $\left(F^{r r}\right)$, which are also consumed in $r$. These two terms are domestic value-added embodied in Country $s$ ' gross exports which are ultimately absorbed by Country $r$.

The third term is Country $s$ ' domestic value-added in its intermediate exports used by the direct importer (Country $r$ ) to produce intermediate exports to the third Countries $t$ for production of the latter's domestic final goods. The fourth term is domestic value-added in Country $s$ ' intermediate exports used by Country $r$ for producing final goods exported to the third Countries $t$. The fifth term is domestic value-added in Country $s$ ' intermediate exports used by Country $r$ to produce intermediate exports to the third Countries $t$ for their production of final goods exports that are exported to other countries (excluding Country $s$ ) as well as shipped back to $r$. The first five terms are the domestic value-added (GDP) embodied in all sectors' gross exports of Country $s$, which include value-added created from all sectors in Country $s$.

The sixth term is domestic value-added of Country $s$ ' sectors' intermediate exports used by the direct importer $(r)$ to produce final goods that are shipped back to the source Country $s$. The seventh term is domestic value-added in Country $s$ ' intermediate exports used by the direct importer $(r)$ to produce intermediate exports to the third Countries $t$ for the latter's production of final goods exports that are shipped back to the source Country $s$. The eighth term is domestic value-added embodied in Country $s$ ' intermediates exports that are used by Country $r$ to produce intermediate exports that return to Country $s$ via its intermediate imports to produce its domestic final goods.

The ninth term is the domestic value-added of Country $s$ ' intermediate exports which return home as it's sectors' intermediate imports and are used for production of Country $s$ ' final exports that are finally consumed abroad. They are parts of the value-added in Country 
$s$ ' final exports and are already counted as one by the first term of the equation. For this reason they are a portion of domestic double counted terms caused by the back and forth intermediate goods trade in order to produce final goods exports in Country $s$. The tenth term is domestic value-added of Country $s$ ' intermediate exports that return home as intermediate imports and are used for production of Country $s$ ' intermediate exports to rest of the world. It is also a domestic double counted portion caused by back and forth intermediate goods trade but is used to produce intermediate goods exports in Country $s$.

The eleventh term is foreign value-added used in Country s' sectors' final goods exports. This includes two parts: foreign value-added from a specific sector and from the other sectors used to produce final exports from Country $s$. The twelfth term is foreign value-added from the third Countries $t$ used by Country $s$ ' sectors to produce final exports from Country $s$. Adding up the first (domestic value-added from source Country $s$ ), eleventh (foreign value-added from Country $r$ ) and twelfth term (foreign value-added from Countries $t$ ) accounts for 100 percent of the value of the final exports in Country $s$ by sector.

The thirteenth term is foreign value-added used to produce intermediates exports of Country $s$, which are then used by Country $r$ to produce its domestic final goods. The fourteenth term is foreign value-added from the third Countries $t$ used to produce intermediates exports of Country $s$ ' sectors, which are then used by Country $r$ to produce its domestic final goods. Summing the eleventh, twelfth, thirteenth, and fourteenth terms yields the total foreign value-added embodied in the gross exports of Country $s$ ' sectors.

The fifteenth and the last terms in the equation are foreign value-added (value-added from Countries $r$ and $t$ ) embodied in the intermediate exports of Country $s$ sectors', which are used by Country $r$ to produce its final and intermediate goods exports to the world (sum of exports to Countries $s$ and $t$ ), which are double counted terms in Country $s$ ' gross exports originating from foreign countries. The sixteen term completely decomposes bilateral gross exports from Country $s$ to Country $r$ into different value-added and double counted components, and their sum equals 100 percent of bilateral trade flows at the sector level.

\subsection{New measure of revealed comparative advantage}

Wang et al. (2013) suggest that the discussion of the forward-linkage based measure of value-added in a sector's exports leads to a revised notion of a country-sector's revealed comparative advantage (RCA). The definition of RCA index of a country-sector is the share of that country-sector's gross exports in the country's total gross exports relative to 
that sector's gross exports from all countries as a share of the world total gross exports (Balasa, 1965).

$$
R C A_{i}^{r}=\frac{e_{i}^{r^{*}}}{\sum_{i}^{n} e_{i}^{r^{*}}} / \frac{\sum_{r}^{G} e_{i}^{r^{*}}}{\sum_{i}^{n} \sum_{r}^{G} e_{i}^{r^{*}}},
$$

where $e_{i}^{r *}$ is the exports of good $i$ of Country $r$ in the N-sector and G-country case. When RCA exceeds one, the country is said to have a revealed comparative advantage in that sector; when RCA is below one, the country is said to have a revealed comparative disadvantage in that sector.

The traditional RCA ignores both domestic production sharing and international production sharing while Wang et al. take into account both kinds of sharing. Traditional RCA ignores the fact that a country-sector may export value-added indirectly via the other country-sectors' exports, but these indirect value-added exports should be included in the measure of a country-sector's comparative advantage. In addition, traditional RCA also ignores that a country-sector's gross exports include foreign contents, which leads to the RCA index inaccurately reflecting the real strength of a country's sector in international competition. A conceptually correct measure of comparative advantage needs to exclude foreign-originated value-added and pure double counted terms in gross exports, but include indirect exports of a sector's value-added through other sectors of the exporting country.

Wang et al. (2013) take into account both domestic and international production sharing, and defines a new measure of a country-sector's RCA as the share of a country-sector's forward linkage based measure of domestic value-added in exports in the country's total domestic value-added in exports relative to that sector's total forward-linkage based domestic value-added from all countries as a share of global value-added in exports. The new RCA measure (WWZ_RCA) is

$$
W W Z \_R C A_{i}^{r}=\frac{v a x \_f_{i}^{r}+r d v \_f_{i}^{r}}{\sum_{i}^{n}\left(v a x \_f_{i}^{r}+r d v \_f_{i}^{r}\right)} / \frac{\sum_{r}^{G}\left(v a x \_f_{i}^{r}+r d v \_f_{i}^{r}\right)}{\sum_{i}^{n} \sum_{r}^{g}\left(v a x \_f_{i}^{r}+r d v \_f_{i}^{r}\right)},
$$

where $v a x \_f_{i}^{r}$ and $r d v \_f_{i}^{r}$ are value-added exports and domestic value-added initially exported but finally return home of sector $i$ in Country $r$, respectively.

According to Wang et al. (2013), If one wishes to understand the contribution of all value added from a given sector to the country's aggregate exports, one should look at the 
forward-linkage based measure of value added exports, which also includes forward-linkage based measure of domestic value-added in a given sector but finally returns home. ${ }^{\text {) }}$

\subsection{Data}

World Input-Output Database (WIOD), a project developed by a consortium of eleven European research institutions funded by the European Commission, is used for our analysis. The WIOD provides a time series of world input-output tables from 1995 to 2011, which can be used to analyze the effects of globalization on trade, the environment, and socio-economic development. It covers 40 economies including all major industrialized countries and major emerging trading countries. In total it covers more than 85 percent of world GDP in 2008 (Timmer et al., 2013a). In addition, a model for the remaining non-covered part of the world economy is made, which is a region called the Rest of the World (RoW), serving as a proxy for all other countries in the world (Timmer et al., 2012). The version of the WIOD used is the one released in November of 2013.

One advantage of the WIOD is that it does not rely on the standard import proportionality assumption when determining the amount of imported intermediates from a given partner that are used to produce one unit of output.7) The WIOD uses detailed trade data at the HS6-digit product level taken from the UN COMTRADE database to allocate products to three use categories based on an extension of the Broad Economic Categories (BEC) classification system as provided by the United Nations: Intermediates, final use, and investment. The proportionality method is then applied only within each category allocation, allowing a country's geographic structure of imports to differ by use category, improving upon the way imports are allocated to users, thus increasing the reliability of value-added trade estimates (Timmer et al., 2012).

6) The value added exports from Country $s$ to Country $r$ based on forward linkages are defined by equation (34) in Wang et al. (2013).

7) Imported proportionality assumption assumes that the share of imports in any product consumed as intermediate consumption or final use is the same for all users. 


\section{Results and Discussions}

\subsection{Gross exports at country-aggregate level}

Figure 1 describes the six economies' gross exports volume from 1995 to 2011. It illustrates the impressive growth in China's exports. From only \$US167.97 billion in 1995 to \$US2,086 billion in 2011, growing more than ten times in 17 years. After China, South Korea also achieved resounding success in exports. Its gross exports were close to Taiwan's in 1995 (\$US148.2 billion for South Korea and \$US126.9 billion for Taiwan) and still very far behind Japan (\$US484 billion in 1995). However, South Korea's exports grew by more than four times in 17 years, reaching \$US612.6 billion in 2011. It moved closer to Japan's exports value (\$US895 billion) and was almost two times higher than that of Taiwan (\$US338 billion) in the same year. India had also shown considerable success in exporting its products, while Indonesia and Taiwan did not show substantial improvements in their exports. Among these countries, Indonesia has the lowest volume of gross exports in recent years. It was only 218.8 billion USD in 2011, which is ten times less than that of China.

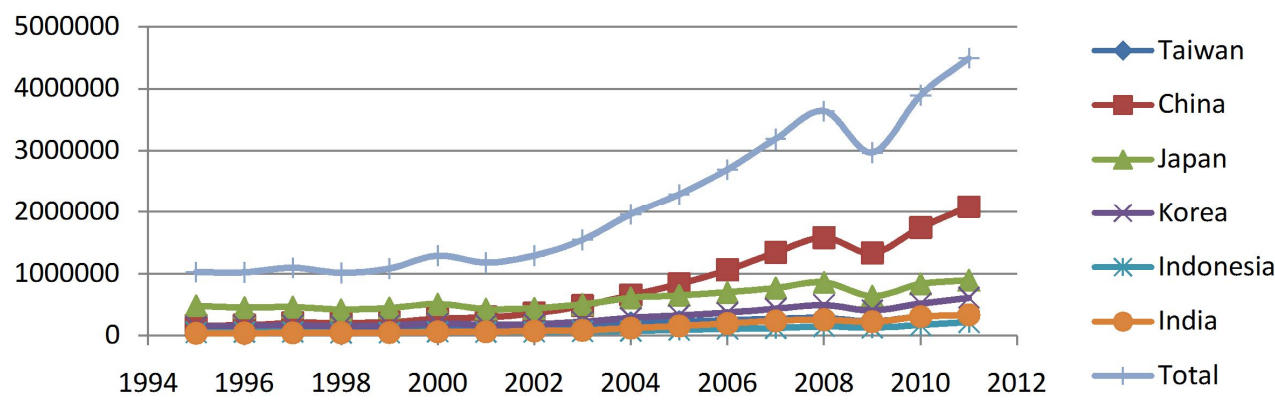

Figure 1.

Gross exports in the period of 1995 - 2011 (unit: million USD)

Source: Author's calculation based on the WIOD database

Trading among the six East Asian countries has also increased significantly from 1995 to 2011, and the East Asian region is now the most important market for these countries' product exports. Figure 2 shows the exports from one country to East Asian market. Amongst the six countries, India has the lowest exports to the other five partners. This country's exports to the region have been quite stable, ranging from 10 percent to 14 percent in its gross exports in recent years. Meanwhile, the proportion of China's product exports to East Asia in its gross exports declined until 2008, where it dipped down to 18.55 
percent before recovering slightly to 21.57 percent in 2011 . This pattern is also observed for Indonesia, where the proportion of product exports to East Asia out of its gross exports declined from 1995 to 2003. From then it became stable at 35 percent to 37 percent until 2009 before increasing quickly, reaching 44.04 percent in 2011. Figure 2 shows that all three emerging countries in East Asia have focused on the regional markets, but their exports to other regions are still higher than that to East Asia. On the contrary, the industrialized and developed countries, namely Japan, South Korea, and Taiwan, have changed their exports concentration from other regions to East Asia. The biggest change was shown by Taiwan. While the share of exports to East Asia in Taiwan's gross exports was 31.67 percent in 1995, this share was up to 50.6 percent in 2011. It means that in 2011, more than half of Taiwan's gross exports had gone to East Asia (which includes only five countries from my sample). Japan and South Korea also tends to export more products to East Asia than to other regions. 35.03 percent and 41.49 percent of Japan and South Korea's gross exports had been sold to East Asia in 2011, respectively. In 1995, these figures were only 21.61 percent and 33.06 percent, respectively.

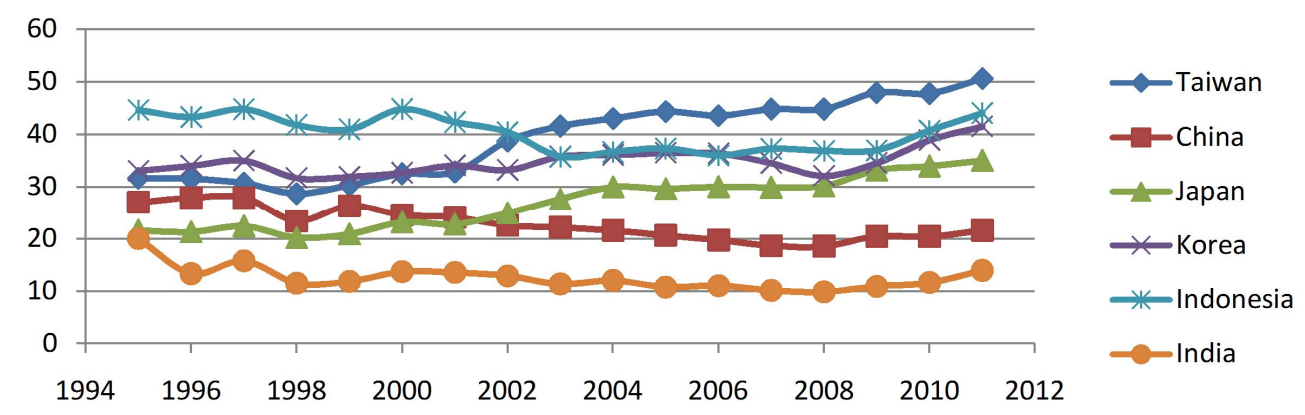

Figure 2.

Exports to East Asian market, as a share of gross exports (unit: \%)

Source: Author's calculation based on the WIOD database

The East Asian production networks are also evaluated based on trade in intermediate products of regional economies. Figure 3 indicates the changes of East Asian producers while integrating into international production networks. All of the developed economies in the sample (Japan, South Korea, and Taiwan) have strongly increased the proportion of intermediate exports to the region in their total exports of intermediates. In 2011, intermediate exports of Taiwan to East Asia accounted for 56.34 percent of its total intermediate exports. In that same year, this figure was 39.47 percent and 48.22 percent for Japan and South Korea, respectively. In other words, these economies show increasingly stronger linkages to the region's production networks. East Asian producers have also used 
large amounts of intermediates from Indonesia. Indonesia's intermediate exports to East Asia has always accounted for more than 40 percent of its total intermediate exports. This reached 49.48 percent in 2011. Conversely, China and India's share of intermediates exports to East Asia in their total intermediate exports declined from 1995 to 2007 (20.47 percent to 12.56 percent) before slightly recovering in 2008. This proportion in China and India's total intermediate exports was up to 23.66 percent and 17.87 percent in 2011, respectively.

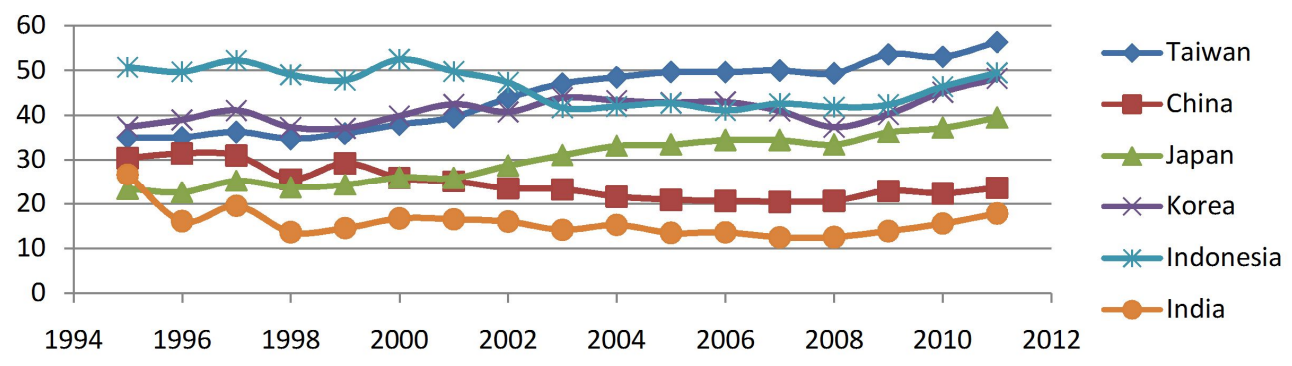

Figure 3.

Intermediate exports to East Asia as a share of total intermediate exports

Source: Author's calculation based on the WIOD database

\subsection{Gross exports at country-sector level}

A country's gross exports are aggregated from country-sectors' gross exports, based on the trade flows from WIOTs. Table 2 shows each country's top five sectors that contribute the largest share to the gross exports annually since 2002 .

Table 2 is a good representation of the six countries' different features. For advanced and developed economies such as Japan, Taiwan, and South Korea, the largest share of their gross exports in recent years are given by "high technology" manufacturing sectors.8) Specifically, it is Transport Equipment for Japan; and Electrical and Optical Equipment for South Korea and Taiwan. For developing countries such as Indonesia and India, the largest share of developing countries' gross exports belongs to "medium-low technology" and "low technology" sector. These are Mining and Quarrying for Indonesia and Manufacturing Nec and Recycling for India. China does not fit these previously observed patterns. Despite being a developing country, the largest contributor to its gross exports has been Electrical and Optical Equipment, a "high technology" sector.9)

8) OECD classified industries into three categories, "high technology", "medium-low technology" and "low technology" manufactures (Eurostat 2011, 2). 
Table 2's bottom row (labeled East Asia 6) shows the five largest contributing sectors to the combined gross exports of all the six East Asian countries. These include Textiles and Textile Products (WIOD sector 4); Basic Metals and Fabricated Metal (WIOD sector 12); Machinery Nec (WIOD sector 13); Electrical and Optical Equipment (WIOD sector 14), and Transport Equipment (WIOD sector 15). The sum of these five sectors accounts for approximately 60 percent of annual East Asia 6's gross exports annually. Textiles and Textile Products and Basic Metals and Fabricated Metal represent "low" and "medium-low technology" sectors, while the remaining three sectors represent "high-technology" manufacturing sectors in international production chains.

Table 2.

Top country-sectors' exports of East Asia (\% of country's gross exports)

\begin{tabular}{cccccccccccc}
\hline & $\begin{array}{c}\text { WIOD } \\
\text { sector }\end{array}$ & $\mathbf{2 0 0 2}$ & $\mathbf{2 0 0 3}$ & $\mathbf{2 0 0 4}$ & $\mathbf{2 0 0 5}$ & $\mathbf{2 0 0 6}$ & $\mathbf{2 0 0 7}$ & $\mathbf{2 0 0 8}$ & $\mathbf{2 0 0 9}$ & $\mathbf{2 0 1 0}$ & $\mathbf{2 0 1 1}$ \\
\hline \multirow{6}{*}{ Taiwan } & 8 & 1.75 & 2.78 & 3.18 & 3.84 & 4.50 & 4.51 & 7.12 & 5.44 & 6.05 & 6.40 \\
& 9 & 6.96 & 7.90 & 8.73 & 9.88 & 9.70 & 9.72 & 10.74 & 10.64 & 10.83 & 11.24 \\
& 12 & 8.24 & 8.73 & 9.29 & 9.58 & 9.76 & 9.79 & 10.42 & 9.35 & 9.04 & 9.88 \\
& 13 & 6.43 & 6.41 & 6.56 & 6.56 & 6.39 & 6.38 & 6.13 & 5.03 & 5.73 & 6.23 \\
& 14 & 43.40 & 42.86 & 44.67 & 44.71 & 46.14 & 46.27 & 42.38 & 45.61 & 45.87 & 43.66 \\
\hline \multirow{6}{*}{ China } & 4 & 14.35 & 13.80 & 12.89 & 13.03 & 12.69 & 12.21 & 11.41 & 12.06 & 11.46 & 11.59 \\
& 9 & 4.00 & 4.13 & 4.19 & 4.31 & 4.12 & 4.70 & 5.21 & 4.87 & 5.15 & 5.61 \\
& 12 & 5.78 & 6.22 & 7.55 & 6.35 & 7.06 & 7.04 & 7.57 & 5.64 & 5.70 & 6.18 \\
& 13 & 4.11 & 4.50 & 4.95 & 5.21 & 5.24 & 6.71 & 7.05 & 6.79 & 6.77 & 6.88 \\
& 14 & 26.40 & 29.91 & 33.21 & 35.55 & 37.04 & 36.41 & 35.24 & 36.50 & 36.65 & 34.58 \\
\hline \multirow{6}{*}{ Japan } & 9 & 6.82 & 6.57 & 6.50 & 6.69 & 6.58 & 6.64 & 6.27 & 7.27 & 6.88 & 6.98 \\
& 12 & 9.43 & 8.92 & 9.23 & 10.06 & 10.47 & 10.90 & 11.87 & 12.08 & 12.29 & 12.84 \\
& 13 & 10.60 & 11.18 & 11.82 & 11.41 & 11.01 & 10.05 & 10.03 & 8.76 & 9.79 & 10.48 \\
& 14 & 24.20 & 23.25 & 23.10 & 21.97 & 21.31 & 20.81 & 19.17 & 20.41 & 19.50 & 18.64 \\
& 15 & 23.23 & 22.40 & 21.32 & 21.59 & 22.29 & 22.77 & 22.34 & 20.16 & 20.87 & 19.92 \\
\hline \multirow{6}{*}{ Korea } & 13 & 5.98 & 6.21 & 6.11 & 6.16 & 6.18 & 6.99 & 6.82 & 6.49 & 6.78 & 6.85 \\
& 14 & 29.27 & 30.46 & 31.14 & 31.38 & 31.06 & 28.32 & 26.09 & 28.44 & 28.45 & 25.98 \\
& 12 & 5.95 & 7.45 & 7.83 & 8.33 & 8.19 & 8.68 & 8.51 & 8.59 & 8.86 & 9.20 \\
& 15 & 15.84 & 15.95 & 16.93 & 17.19 & 17.62 & 18.59 & 19.14 & 19.88 & 19.89 & 19.78 \\
& & & & & & & & & & & \\
& 13 & & & & & & \\
6
\end{tabular}

9) However, it is important to note that the WIOD does not separate China's processing exports from normal China's exports. Therefore, China's gross exports may be overestimated even in the sector level. 


\begin{tabular}{cccccccccccc}
\hline & $\begin{array}{c}\text { WIOD } \\
\text { sector }\end{array}$ & $\mathbf{2 0 0 2}$ & $\mathbf{2 0 0 3}$ & $\mathbf{2 0 0 4}$ & $\mathbf{2 0 0 5}$ & $\mathbf{2 0 0 6}$ & $\mathbf{2 0 0 7}$ & $\mathbf{2 0 0 8}$ & $\mathbf{2 0 0 9}$ & $\mathbf{2 0 1 0}$ & $\mathbf{2 0 1 1}$ \\
\hline \multirow{5}{*}{ Indonesia } & 2 & 15.75 & 16.47 & 16.86 & 20.26 & 21.23 & 19.73 & 20.73 & 23.28 & 24.17 & 25.88 \\
& 3 & 8.87 & 8.78 & 9.79 & 8.87 & 8.90 & 11.59 & 14.20 & 13.14 & 12.86 & 13.57 \\
& 4 & 11.27 & 10.82 & 9.93 & 9.06 & 8.42 & 7.73 & 6.63 & 7.00 & 6.39 & 5.96 \\
& 10.50 & 11.45 & 11.11 & 10.83 & 11.30 & 10.13 & 10.12 & 7.56 & 9.72 & 9.34 \\
& 9 & 4.63 & 4.68 & 4.98 & 4.61 & 4.60 & 5.24 & 4.60 & 4.23 & 4.49 & 5.04 \\
\hline \multirow{4}{*}{ India } & 4 & 18.42 & 16.15 & 13.60 & 12.42 & 10.98 & 9.39 & 8.59 & 8.43 & 7.57 & 7.65 \\
& 12 & 6.77 & 7.85 & 8.25 & 7.81 & 8.42 & 8.27 & 8.49 & 6.57 & 8.02 & 6.54 \\
& 14 & 2.93 & 2.77 & 3.18 & 3.76 & 5.22 & 5.06 & 5.75 & 10.83 & 7.78 & 8.72 \\
& 15 & 2.72 & 3.01 & 3.38 & 3.62 & 3.72 & 3.70 & 5.09 & 5.09 & 6.23 & 6.32 \\
& 16 & 9.12 & 8.84 & 11.84 & 15.27 & 15.04 & 16.47 & 15.62 & 23.27 & 16.88 & 17.50 \\
\hline \multirow{5}{*}{ East Asia } & 4 & 8.07 & 7.68 & 7.13 & 7.20 & 7.14 & 7.03 & 6.58 & 7.10 & 6.68 & 6.88 \\
6 & 12 & 7.28 & 7.39 & 8.13 & 7.88 & 8.33 & 8.38 & 8.90 & 7.79 & 7.81 & 8.05 \\
& 13 & 6.79 & 6.98 & 7.20 & 7.00 & 6.71 & 7.14 & 7.26 & 6.61 & 6.89 & 7.11 \\
& 14 & 25.99 & 26.82 & 28.12 & 28.74 & 29.41 & 28.86 & 27.45 & 29.38 & 29.00 & 27.56 \\
& 15 & 11.52 & 11.15 & 10.71 & 10.37 & 10.21 & 10.33 & 10.50 & 9.80 & 10.07 & 9.69 \\
\hline
\end{tabular}

Source: Author's calculation based on the WIOD database

\subsection{Value chain transition in East Asian production networks}

In this section, we present the results of all sixteen terms developed in Wang et al. (2013). It means that we are not only focusing on domestic value-added (DVA) and foreign value-added (FVA) embodied in gross exports, but also on domestic value-added that returns home (RDV) and pure double counted terms (PDC). All sixteen terms are important to evaluate the relative position of an economy in regional production networks. The different combinations of these terms determine the integration level of a country in production networks. We use time series world input-output tables (WIOTs) from the WIOD and conduct our analysis at both the aggregate and the sector levels. At the aggregate level, it gives an overview of a country's value chain transition in regional production networks. At the sector level, we focus on the Electrical and Optical Equipment industry, which is the biggest exporting sector in East Asia.

\subsubsection{Value chain transition at country aggregate level}

Table 3 summarizes the decomposition results of the six Asian economies' gross 
exports. Table 3 shows that the DVA share in the gross exports of India, Japan, South Korea, and Taiwan declined by about ten to sixteen percent from 1995 to 2011. For China, this component of gross exports fell by approximately eight percent for the same time period. However, the DVA share in Indonesian exports even increased slightly, from 84.31 percent in 1995 to 84.79 percent in 2011, accompanied by a slight decline in foreign value-added's percentage share embodied in its gross exports. The share of FVA in Indonesia's exports declined from 14.6 percent in 2000 to 11.12 percent in 2011.

The FVA's share in Japan's exports was always very low while that of Taiwan was always the highest. In contrast, Japan and China's domestic value-added embodied in gross exports that returns home (RDV) were the highest, followed by South Korea; while the lowest were for Taiwan, India, and Indonesia. Nevertheless, the share of foreign double counting (FDC) in Taiwan's gross exports was always the highest. This may be because of the high share of FVA in Taiwan's gross exports, where goods exports cross borders more than once but are still counted in countries' statistics.

Table 3 however does not provide sufficient information to understand how these economies change their relative position in the international production networks. Furthermore, the results from this table do not indicate the integration of East Asian economies into regional production networks as well as their value chain transition in the last two decades. To evaluate these issues, we analyze the annual movement of those terms' subcomponents, and their proportions that are traded within East Asia.

Table 3.

The proportion of value-added contents in gross exports (unit: \%)

\begin{tabular}{l|ccccc|c|ccccc}
\hline Country & DVA & RDV & DDC & FVA & FDC & Country & DVA & RDV & DDC & FVA & FDC \\
\hline China & & & & & & Japan & & & & & \\
1995 & 83.6 & 0.41 & 0.14 & 13.77 & 2.07 & 1995 & 91.84 & 1.65 & 0.2 & 5.16 & 1.16 \\
2000 & 81.79 & 0.76 & 0.24 & 13.98 & 3.23 & 2000 & 89.59 & 1.72 & 0.28 & 6.55 & 1.85 \\
2005 & 72.34 & 1.21 & 0.74 & 20.22 & 5.49 & 2005 & 86.28 & 1.62 & 0.36 & 8.6 & 3.14 \\
2011 & 75.47 & 1.95 & 0.81 & 17.05 & 4.72 & 2011 & 81.5 & 1.2 & 0.28 & 12.6 & 4.42 \\
India & & & & & & South & & & & & \\
1995 & 89.38 & 0.11 & 0.01 & 9.01 & 1.48 & 1995 & 75.47 & 0.37 & 0.16 & 19.17 & 4.83 \\
2000 & 85.06 & 0.17 & 0.03 & 11.69 & 2.66 & 2000 & 69.79 & 0.35 & 0.22 & 22.9 & 6.75 \\
2005 & 79.32 & 0.39 & 0.09 & 16.43 & 3.52 & 2005 & 67 & 0.44 & 0.35 & 22.86 & 9.35 \\
2011 & 77.89 & 0.33 & 0.08 & 18.54 & 3.15 & 2011 & 59.12 & 0.33 & 0.28 & 29.82 & 10.45
\end{tabular}




\begin{tabular}{c|ccccc|c|ccccc}
\hline Country & DVA & RDV & DDC & FVA & FDC & Country & DVA & RDV & DDC & FVA & FDC \\
\hline Indonesia & & & & & & Taiwan & & & & & \\
1995 & 84.31 & 0.21 & 0.05 & 12.87 & 2.56 & 1995 & 66.63 & 0.18 & 0.14 & 27.09 & 5.95 \\
2000 & 80.55 & 0.19 & 0.07 & 14.60 & 3.87 & 2000 & 63.51 & 0.32 & 0.34 & 27.05 & 8.79 \\
2005 & 80.76 & 0.28 & 0.08 & 13.38 & 5.03 & 2005 & 55.85 & 0.28 & 0.44 & 27.54 & 15.89 \\
2011 & 84.79 & 0.49 & 0.09 & 11.12 & 3.51 & 2011 & 52.24 & 0.17 & 0.31 & 31.71 & 15.58 \\
\hline
\end{tabular}

Notes: DVA is domestic value-added absorbed abroad; RDV is domestic value-added that returns home; DDC is pure double counting from domestic sources; FVA is foreign value-added embodied in country's exports and FDC is pure double counting from foreign sources.

Source: Author's calculation based on the WIOD database

Figure 4 shows the annual trends of the DVA share in the six countries' gross exports. Among them, only Indonesia's DVA proportion in its gross exports shows a stable trend, while those of other countries' are declining. Since the trend of DVA share in gross exports is indicative of the value-added gains for a country from exports, Figure 4 implies that these gains have been relatively reduced, despite East Asian economies' efforts in stimulating their gross exports. Figures $5 \mathrm{a}, 5 \mathrm{~b}$, and $5 \mathrm{c}$ then indicate that the reduction of this component in Japan, South Korea, and Taiwan's gross exports is due to the strong reduction of domestic value-added embodied in final good exports (DVA_FIN), illustrated by the steep slope in these economies' DVA_FIN line. Meanwhile, the domestic value-added absorbed by direct importers through intermediate exports (DVA_INT) have occupied a consistently large share in these economies' domestic value-added exports. The share of DVA_INT for Japan, South Korea, and Taiwan have been slightly increasing in recent years, reaching 41.62 percent, 43.19 percent, and 46.28 percent in 2011, respectively. The contribution of DVA_INTreex (DVA embodied in country's exports of intermediates and then re-exported to other countries) in Japan, South Korea, and Taiwan's gross exports had increased significantly until 2007, reaching 20.62 percent, 19.04 percent, and 17.56 percent for Japan, South Korea, and Taiwan, respectively. These figures then declined slightly to 18.81 percent for Japan, 16.18 percent for Taiwan, and 14.14 percent for South Korea in 2011.

Taiwan emerges as one of the fastest changing economies in international production chains, with its DVA_FIN declining by 21.45 percent as a share of value-added exports from 1995 to 2011, reflecting the sharpest decline among the six East Asian economies. This decline is accompanied by the relatively highest increase in the proportion of domestic value-added exports used by direct importers to produce their exports in Taiwan's value-added exports within East Asia, which increased by 15.04 percent from 1995 to 2011. This evidence implies Taiwan's increasingly important role as a supplier of intermediate 
products, and its growing integration into international production networks. The results also imply the relatively upstream position of Japan, South Korea, and Taiwan in international production networks.

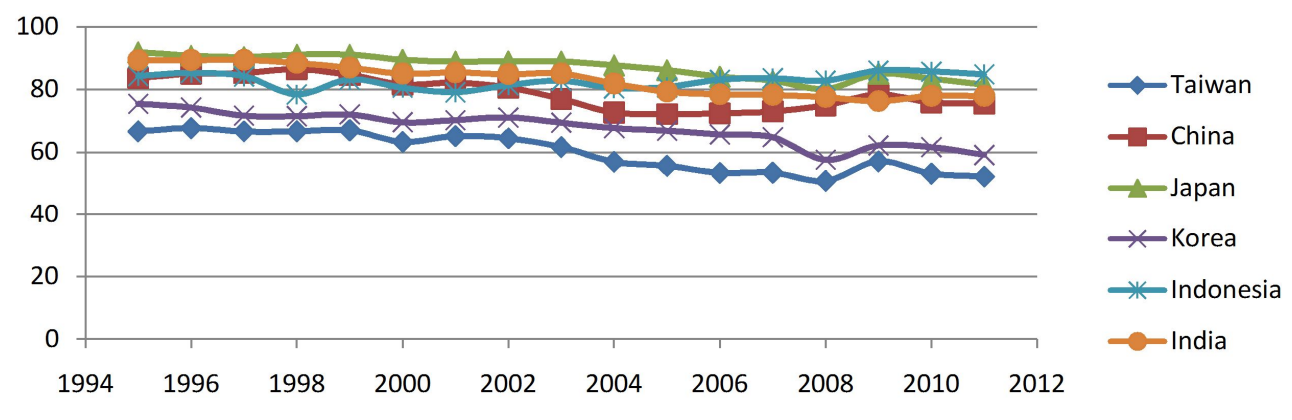

Figure 4.

DVA's share in gross exports (unit: \%)

Source: Author's estimates based on the WIOD database

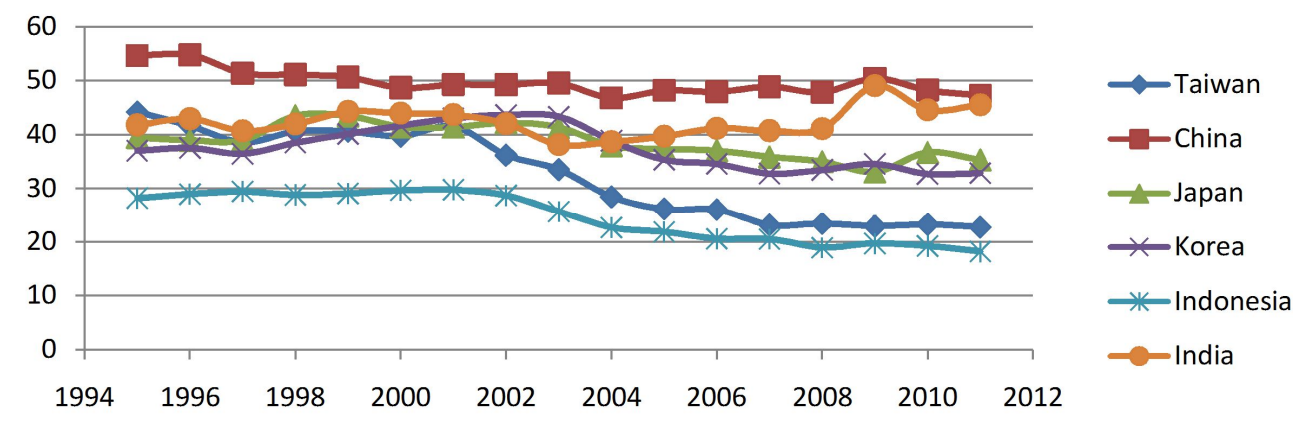

Figure 5a.

DVA_FIN, as a share of domestic value-added exports (unit: \%)

Source: Author's estimates based on the WIOD database 


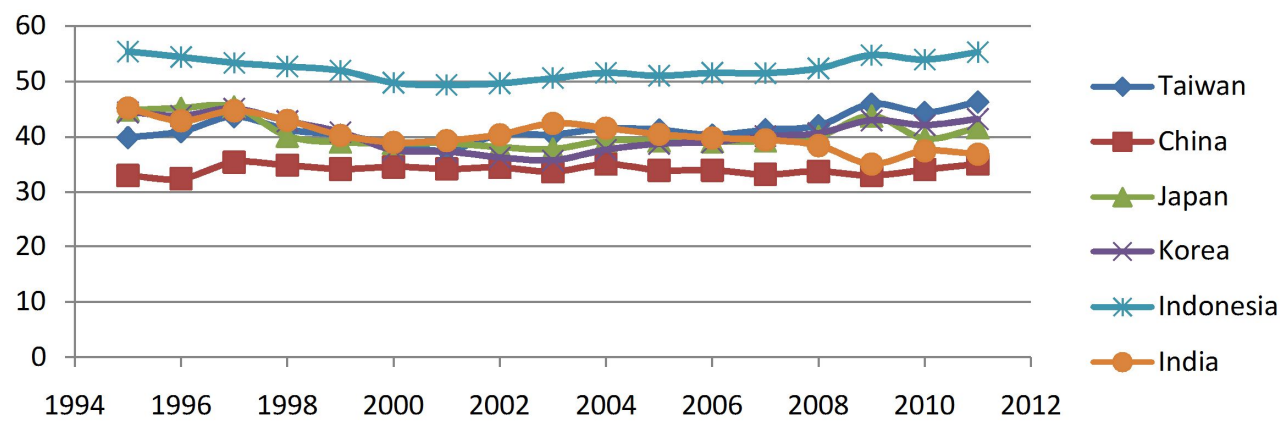

Figure 5b.

DVA_INT, as a share of domestic value-added exports (unit: \%)

Source: Author's estimates based on the WIOD database

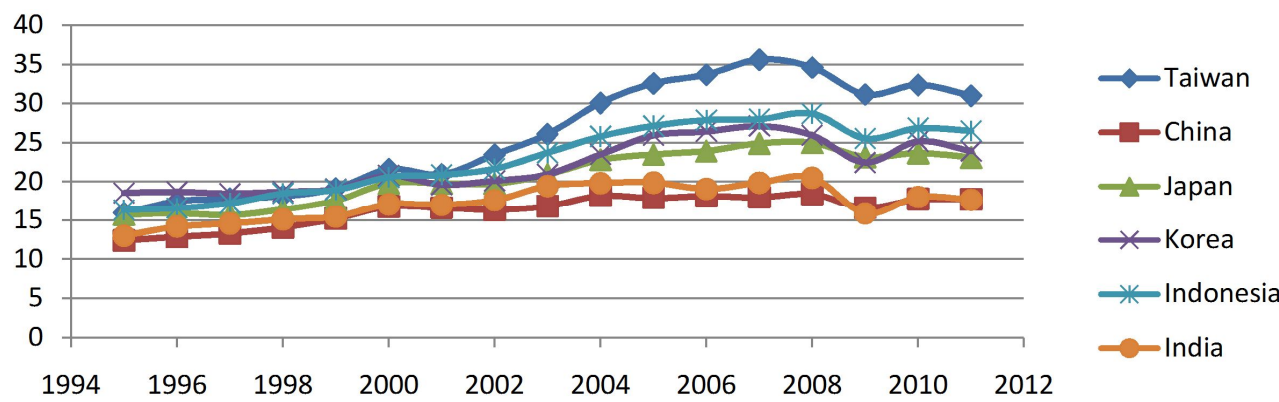

Figure 5c.

DVA_INTreex, as a share of domestic value-added exports (unit: \%)

Source: Author's estimates based on the WIOD database

Figure 6 and 7 underscores Taiwan's increasing role in regional production chains. Taiwan's DVA_INTreex from East Asia accounted for 34.4 percent of its total DVA_INTreex in 1995, the domestic value-added that were re-exported from the region accounted for approximately 60 percent of Taiwan's total DVA_INTreex in 2011. This is an impressive number, indicating that for Taiwan, the East Asian production networks are becoming the most important intermediary producers to re-export its value to other countries. The same pattern was observed for Japan, South Korea, and even Indonesia. Figure 6 shows that the proportion of DVA_INTreex from East Asia in these three economies' total DVA_INTreex has been steadily increasing over time. This reached a peak of 42.84 percent, 45.89 percent, and 52.28 percent for Japan, South Korea, and Indonesia in 2011, respectively. Figure 7 shows that these suppliers are changing the destination of their intermediate exports to East Asia. In other words, East Asia is intensely 
absorbing value-added from Japan, South Korea, and Indonesia for its domestic and export production. These indicators mean that they are increasing their relative role in East Asian production networks, where regional networks have become more important in adding value to their products, which are then re-exported to the world.

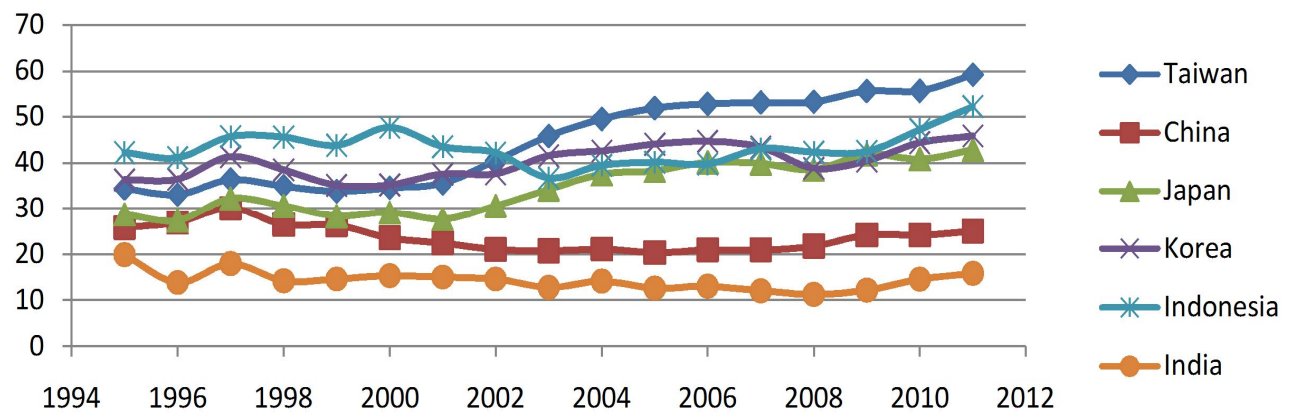

Figure 6.

DVA_INTreex from East Asia, as a share of total DVA_INTreex (unit: \%)

Source: Author's estimates based on WIOD database

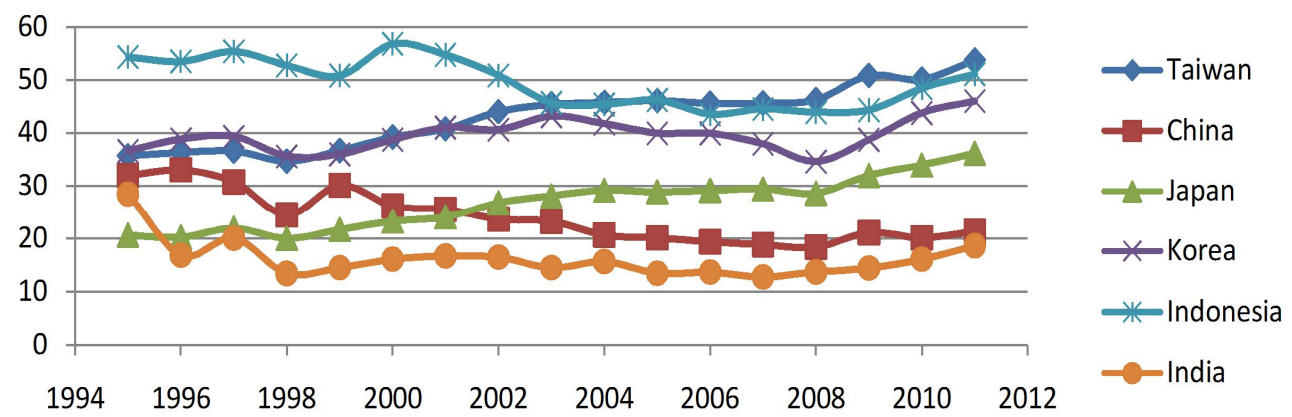

Figure 7.

DVA_INT to East Asia, as a share of total DVA_INT exports (unit: \%)

Source: Author's estimates based on the WIOD database

Table 4 reveals Taiwan, South Korea, and Japan's increasing collaboration with East Asian supply networks to improve their relatively upstream position in international production networks, and bring more regional value to the global production chains. These findings also imply an improvement of regional production networks. They recently can supply more standardized intermediate inputs to high requirement productions from advanced and industrialized economies like Japan, South Korea, and Taiwan.

While Taiwan, South Korea, Japan and India have increasing trends of using inputs 
from East Asia, China showed a declining trend. Table 4 shows a sharp decline in China's importation of value-added from East Asia, as a share of total imported FVA embodied in its gross exports.

Table 4.

FVA, FVA_INT and FVA_INT sourced from East Asia

(unit: \%)*

\begin{tabular}{|c|c|c|c|c|c|c|}
\hline & 1995 & 2000 & 2005 & 2007 & 2009 & 2011 \\
\hline \multicolumn{7}{|l|}{ China } \\
\hline FVA & 13.77 & 13.95 & 20.18 & 19.23 & 15.39 & 17.05 \\
\hline FVA_INT & 4.81 & 5.27 & 7.76 & 7.50 & 5.98 & 7.29 \\
\hline \multicolumn{7}{|l|}{ Indonesia } \\
\hline FVA & 12.87 & 14.60 & 13.38 & 11.36 & 10.44 & 11.12 \\
\hline FVA_INT & 7.35 & 7.60 & 8.09 & 7.08 & 6.02 & 6.64 \\
\hline $\begin{array}{c}\text { FVA_INT sourced from East Asia } \\
\text { India }\end{array}$ & 2.54 & 2.24 & 1.95 & 1.48 & 1.68 & 1.93 \\
\hline FVA & 9.01 & 11.69 & 16.43 & 17.00 & 20.57 & 18.54 \\
\hline FVA_INT & 5.01 & 6.01 & 6.73 & 6.92 & 6.26 & 6.55 \\
\hline $\begin{array}{c}\text { FVA_INT sourced from East Asia } \\
\text { Japan }\end{array}$ & 0.88 & 0.75 & 1.04 & 1.31 & 1.47 & 1.64 \\
\hline FVA & 5.16 & 6.54 & 8.58 & 10.96 & 9.95 & 12.60 \\
\hline FVA_INT & 2.80 & 3.16 & 4.54 & 5.97 & 5.89 & 7.72 \\
\hline FVA_INT sourced from East Asia & 0.68 & 0.79 & 1.17 & 1.52 & 1.60 & 2.27 \\
\hline \multicolumn{7}{|l|}{ South Korea } \\
\hline FVA & 19.17 & 22.82 & 22.80 & 23.79 & 27.90 & 29.82 \\
\hline FVA_INT & 10.64 & 11.65 & 12.93 & 14.32 & 16.94 & 18.73 \\
\hline $\begin{array}{c}\text { FVA_INT sourced from East Asia } \\
\text { Taiwan }\end{array}$ & 3.37 & 3.40 & 4.05 & 4.24 & 5.38 & 5.62 \\
\hline FVA & 27.09 & 26.94 & 27.45 & 27.75 & 28.15 & 31.70 \\
\hline FVA_INT & 13.33 & 13.18 & 17.43 & 18.47 & 19.83 & 22.37 \\
\hline FVA_INT sourced from East Asia & 4.76 & 4.77 & 6.20 & 6.51 & 7.31 & 7.85 \\
\hline
\end{tabular}

Note: * percentage share of gross exports in selected years.

Source: Author's calculation based on the WIOD database 


\subsubsection{Value chain transition in Electrical and Optical Equipment industry}

In this section, we decompose gross exports of the six East Asian countries at the sector level. To limit the scope of this study, the decomposition will be done on the sector that has the largest exports value within East Asia, which is the Electrical and Optical Equipment sector. We investigate what components are contributing the most to this sector's gross exports for each of the six countries. Furthermore, we measure how much domestic value-added is embodied in a sector's manufactured exports. It is worth mentioning that domestic value-added embedded in a country sector's exports includes not only value-added generated in this sector but also value-added generated in other domestic sectors used as inputs in the production of this sector's exports. All sixteen terms calculated based on seventeen-year time series data from the WIOD give out the development of value chain of this important industry in East Asian production networks.

Table 5 shows the domestic value-added absorbed abroad via Electrical and Optical Equipment exports of the six East Asian economies. It reveals that all the six producers have increased their DVA exports in value terms. However, all the countries in the sample also show a downward trend in the DVA share of their Electrical and Optical Equipment exports. Similar to the case at the aggregate level, this finding implies that these countries have not increased the value-added gains for them from exports of electronic products.

Table 5.

DVA exports, as a share of Electrical and Optical Equipment exports

\begin{tabular}{lccccccccc}
\hline & $\mathbf{1 9 9 5}$ & $\mathbf{2 0 0 0}$ & $\mathbf{2 0 0 5}$ & $\mathbf{2 0 0 6}$ & $\mathbf{2 0 0 7}$ & $\mathbf{2 0 0 8}$ & $\mathbf{2 0 0 9}$ & $\mathbf{2 0 1 0}$ & $\mathbf{2 0 1 1}$ \\
\hline \multicolumn{1}{c}{ China } & & & & & & & & & \\
Exports & 34.03 & 68.94 & 296.92 & 392.70 & 488.06 & 557.35 & 486.64 & 638.98 & 721.42 \\
DVA (\%) & 77.31 & 72.77 & 59.65 & 60.84 & 62.07 & 65.67 & 69.78 & 66.92 & 67.37 \\
$\quad$ India & & & & & & & & & \\
Exports & 1.26 & 1.86 & 5.88 & 10.27 & 12.22 & 14.92 & 24.61 & 23.99 & 29.47 \\
DVA (\%) & 88.93 & 81.88 & 79.35 & 75.62 & 75.62 & 78.81 & 80.45 & 80.53 & 80.18 \\
$\quad$ Indonesia & & & & & & & & & \\
Exports & 2.83 & 7.59 & 8.33 & 8.49 & 8.58 & 9.58 & 9.51 & 11.67 & 12.56 \\
DVA (\%) & 71.17 & 69.27 & 70.09 & 73.96 & 73.40 & 68.18 & 72.61 & 70.70 & 68.99 \\
$\quad$ Japan & & & & & & & & & \\
Exports & 124.27 & 136.06 & 143.28 & 149.55 & 160.38 & 165.03 & 130.64 & 162.86 & 166.93 \\
DVA (\%) & 91.48 & 87.93 & 85.63 & 83.64 & 82.72 & 81.15 & 84.67 & 83.16 & 82.18
\end{tabular}




\begin{tabular}{lccccccccc}
\hline & $\mathbf{1 9 9 5}$ & $\mathbf{2 0 0 0}$ & $\mathbf{2 0 0 5}$ & $\mathbf{2 0 0 6}$ & $\mathbf{2 0 0 7}$ & $\mathbf{2 0 0 8}$ & $\mathbf{2 0 0 9}$ & $\mathbf{2 0 1 0}$ & $\mathbf{2 0 1 1}$ \\
\hline \multicolumn{1}{c}{ South Korea } & & & & & & & & & \\
Exports & 40.64 & 60.37 & 102.55 & 115.66 & 123.19 & 129.13 & 115.96 & 147.82 & 159.19 \\
DVA (\%) & 71.43 & 64.00 & 64.18 & 64.67 & 63.75 & 58.22 & 60.80 & 62.04 & 62.17 \\
$\quad$ Taiwan & & & & & & & & & \\
Exports & 41.82 & 77.81 & 100.91 & 115.34 & 127.79 & 122.37 & 104.88 & 142.94 & 147.65 \\
DVA (\%) & 55.75 & 54.21 & 49.78 & 49.01 & 49.42 & 50.38 & 53.45 & 49.97 & 51.06 \\
\hline
\end{tabular}

Note: The exports rows are in billion USD.

Source: Author's calculation based on the WIOD database

Table 6 presents the domestic value-added exports to East Asia, as a share of total DVA embodied in Electrical and Optical Equipment exports. As with the aggregate level results, Table 6 states the changing market orientation of Taiwan, South Korea, and Japan's exports. These economies' share of DVA exports to East Asia in total DVA exports only accounted for approximately 20 percent in 1995, but starting from 2009 this share has increased to more than 50 percent for Japan and South Korea, and to more than 60 percent for Taiwan. These figures exceed the country-aggregate average, as mentioned previously.

\section{Table 6.}

DVA to East Asia, as a share of DVA exports

\begin{tabular}{ccccccccccc}
\hline & $\mathbf{1 9 9 5}$ & $\mathbf{2 0 0 0}$ & $\mathbf{2 0 0 5}$ & $\mathbf{2 0 0 6}$ & $\mathbf{2 0 0 7}$ & $\mathbf{2 0 0 8}$ & $\mathbf{2 0 0 9}$ & $\mathbf{2 0 1 0}$ & $\mathbf{2 0 1 1}$ \\
\hline China & & & & & & & & & \\
DVA to EA & 4.56 & 9.62 & 31.29 & 39.22 & 48.00 & 57.82 & 53.98 & 69.79 & 82.14 \\
Share in DVA & 17.33 & 19.18 & 17.66 & 16.42 & 15.85 & 15.80 & 15.90 & 16.32 & 16.90 \\
$\quad$ India & & & & & & & & & \\
DVA to EA & 0.22 & 0.14 & 0.48 & 0.83 & 1.16 & 1.17 & 2.71 & 2.66 & 3.95 \\
share in DVA & 19.97 & 9.39 & 10.27 & 10.63 & 12.61 & 9.97 & 13.71 & 13.77 & 16.73 \\
$\quad$ Indonesia & & & & & & & & & \\
DVA to EA & 0.31 & 1.24 & 1.20 & 1.40 & 1.47 & 1.64 & 1.68 & 2.16 & 2.21 \\
Share in DVA & 15.41 & 23.65 & 20.56 & 22.36 & 23.27 & 25.13 & 24.40 & 26.20 & 25.52 \\
$\quad$ Japan & & & & & & & & & \\
DVA to EA & 23.92 & 32.65 & 50.53 & 53.78 & 58.74 & 60.63 & 54.22 & 67.94 & 69.81 \\
Share in DVA & 21.04 & 27.29 & 41.19 & 42.99 & 44.27 & 45.27 & 49.01 & 50.16 & 50.89
\end{tabular}




\begin{tabular}{lccccccccc}
\hline & $\mathbf{1 9 9 5}$ & $\mathbf{2 0 0 0}$ & $\mathbf{2 0 0 5}$ & $\mathbf{2 0 0 6}$ & $\mathbf{2 0 0 7}$ & $\mathbf{2 0 0 8}$ & $\mathbf{2 0 0 9}$ & $\mathbf{2 0 1 0}$ & $\mathbf{2 0 1 1}$ \\
\hline \multicolumn{1}{c}{ South Korea } & & & & & & & & & \\
DVA to EA & 5.57 & 10.17 & 27.79 & 33.26 & 35.65 & 35.62 & 35.71 & 47.88 & 50.77 \\
$\begin{array}{c}\text { Share in DVA } \\
\quad 19.20\end{array}$ & 26.31 & 42.22 & 44.47 & 45.40 & 47.38 & 50.65 & 52.21 & 51.30 \\
$\quad$ Taiwan & & & & & & & & & \\
DVA to EA & 5.14 & 12.01 & 25.54 & 29.75 & 33.67 & 34.57 & 34.08 & 42.62 & 46.73 \\
Share in DVA & 22.05 & 28.47 & 50.85 & 52.63 & 53.33 & 56.07 & 60.79 & 59.67 & 61.99 \\
\hline
\end{tabular}

Note: The exports rows are in billion USD.

Source: Author's calculation based on the WIOD database

\subsubsection{Revealed comparative advantage}

There are the big differences in RCA indices between traditional and Wang et al.'s approach. China and Taiwan fell in RCA using value-added approach. In contrast, Japan and South Korea rose in RCA. The results indicate that Taiwan, and especially China have used a significantly imported intermediates to produce electronic sector's exports. At the same time, Japan and South Korea's domestic value-added contribution to their RCA is relatively underestimated if one uses gross trade statistic to state the comparative advantage of their electronic industry in global market.

In the case of Japan, both gross trade and value-added approach show the declining trend of its Electrical and Optical Equipment sector's RCA over time. This implies that other countries have begun to overtake Japan in its dominance of electronic export production, where China is a notable example, among others. Despite that China fell in RCA index, it has still been higher than Japan's RCA since 2006 (it has been higher than Japan's RCA since 2001, using gross trade terms). Figure 8 indicates that Taiwan emerges at the top, having the highest RCA index among the countries in the sample. Taiwan's RCA index based on Wang et al.'s framework has always been higher than three since 2007. Following at a close second is South Korea. Its RCA index has reached 2.5 in 2004, increasing mildly to 2.7 in 2011. These results suggest that Taiwan and South Korea have the most comparative advantage among the six East Asian countries in the Electrical and Optical Equipment industry.10) Meanwhile, both traditional and Wang et al.'s approach give the results that Indonesia and India comparative advantages have not changed much

10) While Taiwan and South Korea's revealed comparative advantage ranks first and second in the electronics industry, their RCA index in the textile sector is declining sharply. This result implies the transformation of these two economies' value chains to move upstream in global production networks. 
from 1995. This means they are not yet ready to compete with other producers in the international market.

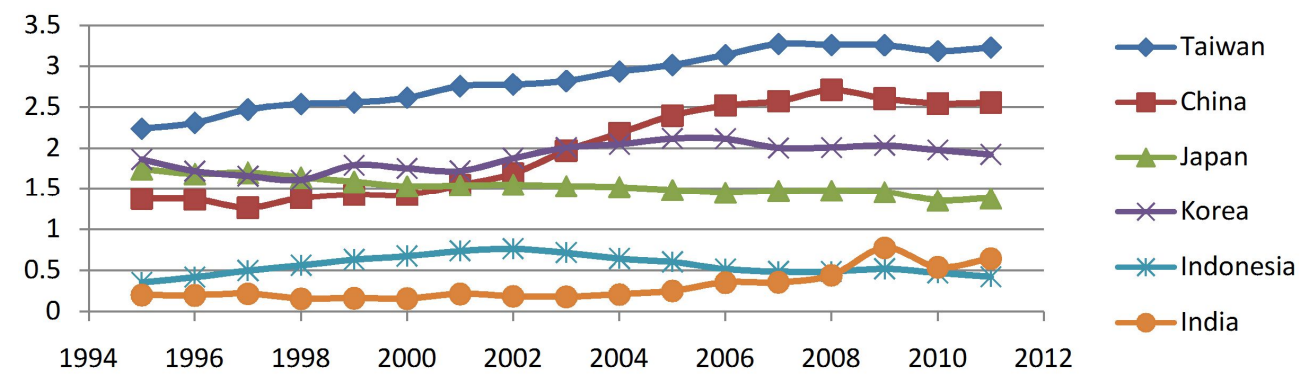

Figure 8a.

Traditional RCA indices for Electrical and Optical Equipment exports

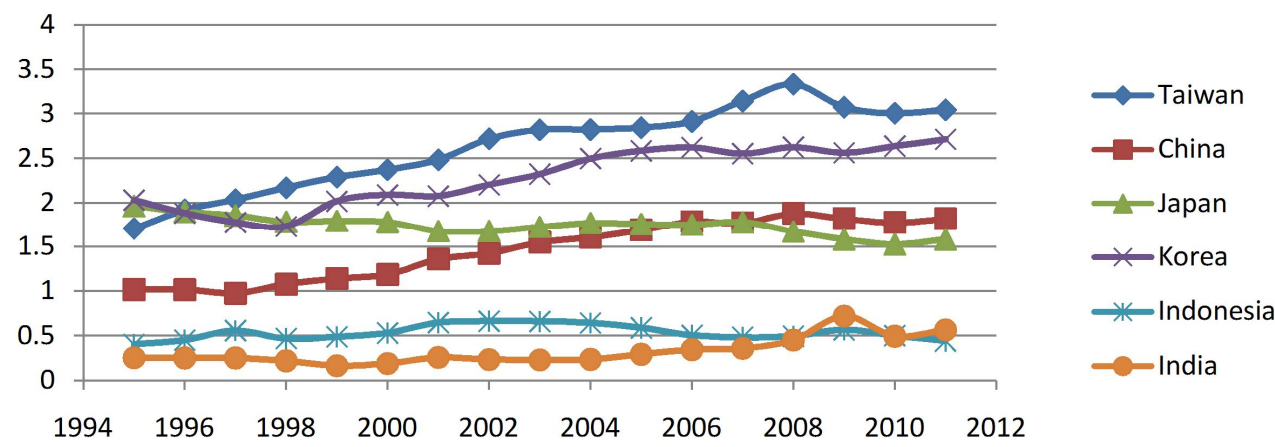

Figure 8b.

New RCA indices for Electrical and Optical Equipment exports

Source: Author's estimates based on the WIOD database

\subsection{Taiwan and South Korea's bilateral trade relationship}

We evaluate the production cooperation between Taiwan and South Korea at the aggregate and sector levels, focusing on the Electrical and Optical Equipment industry. Table 7 states that bilateral aggregate trade between Taiwan and South Korea are increasing over time, with exports from South Korea to Taiwan being consistently higher than exports from Taiwan to South Korea. From Table 7, we find that Taiwan and South Korea are improving their bilateral economic transaction. Furthermore, Taiwan is focusing more on the South Korean market. Table 7 adduces that the proportion of Taiwan's exports to South Korea in its gross exports grew by approximately two times within two decades, from 2.07 
in 1995 to 4.03 percent in 2011. In contrast, the share of exports to Taiwan in South Korea's gross exports decreased, from 3.39 percent in 1997 to 2.67 percent in 2011, although South Korea's exports to Taiwan have increased in value terms. The same pattern was found at the sector level (Electrical and Optical Equipment industry).

Table 7.

Bilateral trade between Taiwan and South Korea (unit: billion USD)

\begin{tabular}{clccccc}
\hline & & $\mathbf{1 9 9 5}$ & $\mathbf{2 0 0 1}$ & $\mathbf{2 0 0 5}$ & $\mathbf{2 0 0 9}$ & $\mathbf{2 0 1 1}$ \\
\hline \multirow{4}{*}{ Aggregate level } & Taiwan's exports & 2.63 & 3.91 & 7.53 & 8.81 & 13.63 \\
& \% in Taiwan gross exports & 2.07 & 2.69 & 3.34 & 3.83 & 4.03 \\
& South Korea's exports & 5.02 & 5.88 & 12.70 & 9.73 & 16.34 \\
& \% in South Korea gross exports & 3.39 & 3.40 & 3.89 & 2.39 & 2.67 \\
\hline \multirow{2}{*}{ Sector level } & Taiwan's exports & 1.11 & 2.69 & 4.95 & 5.61 & 8.19 \\
(Electrical and & \% in Taiwan gross exports & 2.65 & 4.18 & 4.91 & 5.35 & 5.55 \\
Optical Equipment) & South Korea's exports & 1.99 & 2.83 & 7.41 & 4.14 & 5.95 \\
& \% in South Korea gross exports & 4.91 & 5.90 & 7.22 & 3.57 & 3.74 \\
\hline
\end{tabular}

Source: Author's calculation based on the WIOD database

In the previous section, we found that Taiwan and South Korea have shifted their export orientation from the West to the East. Table 8 consolidates these findings by showing that these two economies' individual exports to China as a share of their respective gross exports have increased approximately three times in seventeen years. While this percentage was only 12.64 percent for Taiwan and 9.26 percent for South Korea's gross exports in 1995, it grew to 37.62 percent for Taiwan and 25.71 percent for South Korea in 2011. These results indicate that China has become the most important market for both Taiwan and South Korea's exports. This finding supports that of Nanto and Chanlett-Avery (2006), who investigate the effects of China's changes on Taiwan, South Korea, and Japan. The results from Table 8 even suggest that between Taiwan and South Korea, the former's exports have the greater dependence on China, and therefore any negative change in the Chinese market may cause a bigger shock to Taiwan than to South Korea.

Looking at the bilateral gross trade of Taiwan and South Korea with China at the aggregate level briefly suggest that South Korea has caught up to and overtaken Taiwan in their competition to meet China's market demands. Meanwhile at the sector level (within electrical and optical sector), Taiwan has been dominating this competition in the Chinese market, but South Korea has been catching up. However, looking at trade values with China in gross terms does not accurately quantify the linkages of Taiwan and South Korea with China's domestic and export production. Wang et al.'s decomposition of gross exports 
reveals reliable indicators to evaluate the importance of Taiwan and South Korea in supplying intermediate products to China's production. Using these results, this dissertation can analyze which of the two countries has been dominating or has the greater comparative advantage over the other in its exports to China.

\section{Table 8.}

Taiwan and South Korea's exports to China

\begin{tabular}{ccccccccccc}
\hline & & $\mathbf{1 9 9 5}$ & $\mathbf{2 0 0 0}$ & $\mathbf{2 0 0 5}$ & $\mathbf{2 0 0 6}$ & $\mathbf{2 0 0 7}$ & $\mathbf{2 0 0 8}$ & $\mathbf{2 0 0 9}$ & $\mathbf{2 0 1 0}$ & $\mathbf{2 0 1 1}$ \\
\hline \multirow{5}{*}{$\begin{array}{c}\text { Aggregate } \\
\text { level }\end{array}$} & I & 16.04 & 28.09 & 70.80 & 79.85 & 90.26 & 92.53 & 80.84 & 110.45 & 127.24 \\
& II & 12.64 & 16.45 & 31.37 & 31.94 & 32.68 & 32.04 & 35.16 & 35.44 & 37.62 \\
& IV & 9.26 & 12.87 & 20.67 & 21.41 & 20.91 & 21.22 & 24.20 & 25.64 & 25.71 \\
& V & 1.17 & 1.10 & 1.05 & 1.00 & 0.99 & 0.88 & 0.82 & 0.83 & 0.81 \\
\hline \multirow{3}{*}{ Sector } & I & 3.96 & 9.91 & 39.58 & 47.40 & 54.64 & 55.49 & 51.78 & 69.35 & 75.78 \\
level & II & 9.46 & 12.74 & 39.22 & 41.09 & 42.76 & 45.35 & 49.37 & 48.51 & 51.33 \\
& III & 1.71 & 6.42 & 29.63 & 37.36 & 41.15 & 48.19 & 48.54 & 64.22 & 66.08 \\
& IV & 4.20 & 10.63 & 28.90 & 32.30 & 33.40 & 37.32 & 41.86 & 43.45 & 41.51 \\
& V & 2.32 & 1.55 & 1.34 & 1.27 & 1.33 & 1.15 & 1.07 & 1.08 & 1.15 \\
\hline
\end{tabular}

Source: Author's calculation based on the WIOD database.

Legend: I is Taiwan's exports to China (billion USD); II is I as a share of Taiwan's gross exports (\%); III is South Korea's exports to China (billion USD); IV is III as a share of Taiwan's gross exports (\%); V is the ratio between I and III.

The values of Taiwan's domestic value-added absorbed in China are presented in table 9a. At the aggregate level, it shows that Taiwan's DVA absorbed in China has increased over time. Furthermore, a large part of Taiwan's DVA absorbed in China has been via intermediate products and intermediates that are then re-exported to third countries. The results indicate that China has increased cooperation with Taiwan to cater to its own domestic and export production at the aggregate level. Similarly, the same results are observed at the sector level. In the table, we can find thatTaiwan's DVA_FIN absorbed by China's final demand increased from US\$0.6 billion in 1995 to US\$3.11 billion in 2011. Meanwhile, Taiwan's DVA_INT and DVA_INTreex absorbed by China's domestic and export production increased from US\$1.13 billion and US\$0.48 billion in 1995, to US\$18.21 billion and US\$17.32 billion in 2011, respectively. Table 9a also reveals that Taiwan's DVA embodied in Electrical and Optical Equipment exports to China contributed approximately 60 percent in Taiwan's total DVA absorbed in China at the aggregate level, mostly via intermediate products. 
Table 9b presents the values of South Korea's domestic value-added absorbed in China. This table also confirms the increasing trend of South Korea's DVA absorbed by China's final demand, as well as its domestic and export production. More than 80 percent of South Korea's DVA absorbed in China has been due to intermediate exports. The results thus imply that the cooperation of South Korea with China at the aggregate level has also intensified over time. The same is true at the sector level, where South Korea has made steady strides to strengthen its linkages with China's domestic and export production within the Electrical and Optical Equipment industry. It also reveals that South Korea's DVA embodied in Electrical and Optical Equipment exports to China contributed approximately 46 percent in South Korea's total DVA absorbed in China at the aggregate level.

Table 9c shows the ratio of domestic value-added absorbed in China between Taiwan and South Korea. At the aggregate level, this table states that the ratio of Taiwan's DVA_FIN to South Korea DVA_FIN, which are both absorbed in China, has been declining sharply, from 1.43 in 1995 to 0.4 in 2011. This implies that China's final demand has been using more products from South Korea than from Taiwan.

Table 9a.

Taiwan's DVA absorbed in China (unit: billion USD)

\begin{tabular}{ccccccccccc}
\hline & & $\mathbf{1 9 9 5}$ & $\mathbf{2 0 0 0}$ & $\mathbf{2 0 0 5}$ & $\mathbf{2 0 0 6}$ & $\mathbf{2 0 0 7}$ & $\mathbf{2 0 0 8}$ & $\mathbf{2 0 0 9}$ & $\mathbf{2 0 1 0}$ & $\mathbf{2 0 1 1}$ \\
\hline \multirow{2}{*}{$\begin{array}{c}\text { Aggregate } \\
\text { level }\end{array}$} & I & 2.53 & 3.36 & 4.59 & 4.43 & 4.54 & 5.40 & 4.29 & 6.72 & 6.65 \\
& II & 5.33 & 9.58 & 17.10 & 18.07 & 20.32 & 20.54 & 23.45 & 28.03 & 33.88 \\
& III & 2.49 & 4.49 & 16.04 & 18.52 & 21.40 & 19.78 & 16.83 & 22.28 & 24.26 \\
\hline \multirow{2}{*}{$\begin{array}{c}\text { Sector } \\
\text { level }\end{array}$} & I & 0.60 & 1.21 & 2.54 & 2.44 & 2.43 & 2.10 & 1.86 & 2.38 & 3.11 \\
& II & 1.13 & 2.67 & 7.26 & 8.55 & 9.96 & 11.44 & 13.39 & 15.81 & 18.21 \\
& III & 0.48 & 1.50 & 9.89 & 12.22 & 14.58 & 14.36 & 12.39 & 16.43 & 17.32 \\
\hline
\end{tabular}

Table 9b.

South Korea's DVA absorbed in China (unit: billion USD)

\begin{tabular}{ccccccccccc}
\hline & & $\mathbf{1 9 9 5}$ & $\mathbf{2 0 0 0}$ & $\mathbf{2 0 0 5}$ & $\mathbf{2 0 0 6}$ & $\mathbf{2 0 0 7}$ & $\mathbf{2 0 0 8}$ & $\mathbf{2 0 0 9}$ & $\mathbf{2 0 1 0}$ & $\mathbf{2 0 1 1}$ \\
\hline \multirow{2}{*}{$\begin{array}{c}\text { Aggregate } \\
\text { level }\end{array}$} & I & 1.77 & 2.94 & 7.64 & 9.02 & 9.12 & 11.21 & 11.76 & 15.58 & 16.55 \\
& II & 5.56 & 9.58 & 21.13 & 24.03 & 27.40 & 27.66 & 31.46 & 41.00 & 48.61 \\
& III & 2.66 & 4.07 & 14.82 & 17.54 & 20.44 & 19.00 & 15.89 & 22.93 & 24.39 \\
\hline \multirow{2}{*}{$\begin{array}{c}\text { Sector } \\
\text { level }\end{array}$} & I & 0.32 & 1.24 & 4.30 & 5.46 & 4.75 & 5.05 & 5.70 & 6.69 & 7.63 \\
& II & 0.60 & 1.86 & 7.18 & 9.29 & 10.38 & 11.91 & 14.31 & 18.95 & 19.85 \\
& III & 0.30 & 1.00 & 7.45 & 9.30 & 10.97 & 10.96 & 9.42 & 14.08 & 13.46 \\
\hline
\end{tabular}


Table 9c.

The ratio of DVA absorbed in China between Taiwan and South Korea

\begin{tabular}{ccccccccccc}
\hline & & $\mathbf{1 9 9 5}$ & $\mathbf{2 0 0 0}$ & $\mathbf{2 0 0 5}$ & $\mathbf{2 0 0 6}$ & $\mathbf{2 0 0 7}$ & $\mathbf{2 0 0 8}$ & $\mathbf{2 0 0 9}$ & $\mathbf{2 0 1 0}$ & $\mathbf{2 0 1 1}$ \\
\hline \multirow{2}{*}{$\begin{array}{c}\text { Aggregate } \\
\text { level }\end{array}$} & I & 1.43 & 1.14 & 0.60 & 0.49 & 0.50 & 0.48 & 0.36 & 0.43 & 0.40 \\
& II & 0.96 & 1.00 & 0.81 & 0.75 & 0.74 & 0.74 & 0.75 & 0.68 & 0.70 \\
& III & 0.94 & 1.10 & 1.08 & 1.06 & 1.05 & 1.04 & 1.06 & 0.97 & 0.99 \\
\hline \multirow{2}{*}{$\begin{array}{c}\text { Sector } \\
\text { level }\end{array}$} & I & 1.85 & 0.98 & 0.59 & 0.45 & 0.51 & 0.42 & 0.33 & 0.36 & 0.41 \\
& II & 1.89 & 1.44 & 1.01 & 0.92 & 0.96 & 0.96 & 0.94 & 0.83 & 0.92 \\
& III & 1.60 & 1.50 & 1.33 & 1.32 & 1.33 & 1.31 & 1.32 & 1.17 & 1.29 \\
\hline
\end{tabular}

Source: Author's calculation based on the WIOD database.

Legend: $\mathbf{I}$ is domestic value-added absorbed in China via final goods exports; II is domestic value-added absorbed in China via intermediate imports; III is domestic value-added absorbed in China via intermediate imports and then re-exported to third countries. All are in billion USD.

Table 10 presents Taiwan and South Korea's value-added embodied in China's gross exports at both country-aggregate and country-sector levels. The results show that China's export production has increasingly used more value-added sourced from Taiwan and South Korea since 1995. At the aggregate level, the FVA sourced from Taiwan and South Korea embodied in China's gross exports started out at US\$2.31 billion and US\$2.61 billion in 1995 , respectively. These values increased to US\$21.59 billion and US\$23.60 billion for Taiwan and South Korea, respectively.

Table 10.

FVA sourced from Taiwan and South Korea embodied in China's gross exports

(unit: billion USD)

\begin{tabular}{ccccccccccc}
\hline & & $\mathbf{1 9 9 5}$ & $\mathbf{2 0 0 0}$ & $\mathbf{2 0 0 5}$ & $\mathbf{2 0 0 6}$ & $\mathbf{2 0 0 7}$ & $\mathbf{2 0 0 8}$ & $\mathbf{2 0 0 9}$ & $\mathbf{2 0 1 0}$ & $\mathbf{2 0 1 1}$ \\
\hline \multirow{2}{*}{$\begin{array}{c}\text { Aggregate } \\
\text { level }\end{array}$} & I & 2.31 & 4.00 & 14.47 & 16.72 & 19.38 & 17.73 & 15.16 & 20.09 & 21.59 \\
& II & 2.61 & 3.85 & 14.66 & 17.35 & 20.42 & 18.45 & 15.32 & 22.05 & 23.60 \\
& III & 0.88 & 1.04 & 0.99 & 0.96 & 0.95 & 0.96 & 0.99 & 0.91 & 0.91 \\
\hline \multirow{2}{*}{$\begin{array}{c}\text { Sector } \\
\text { level }\end{array}$} & I & 0.58 & 1.47 & 9.28 & 11.26 & 13.17 & 12.41 & 10.79 & 14.34 & 14.97 \\
& II & 0.51 & 1.18 & 8.33 & 10.07 & 11.88 & 10.91 & 9.27 & 13.62 & 13.69 \\
& III & 1.15 & 1.25 & 1.11 & 1.12 & 1.11 & 1.14 & 1.16 & 1.05 & 1.09 \\
\hline
\end{tabular}

Source: Author's calculation based on the WIOD database.

Legend: I is FVA sourced from Taiwan embodied in China's gross exports; II is FVA sourced from South Korea in China's gross exports; III is the ratio of I to II. 


\section{Concluding Remarks}

This paper presents decomposition results at the country-aggregate and country-sector levels for six East Asian countries, and bilateral-aggregate and bilateral-sector levels for Taiwan and South Korea. Wang et al.'s method goes beyond extracting value-added exports from gross exports, and extracts additional useful information about the structure of international production sharing at a disaggregated level, which has never been correctly done before in the literature. The results show that the share of DVA has stabled or declined in all the six East Asian economies' gross exports. This indicates the relative reduction of the value-added gains for these economies from exports. In other words, East Asia's countries are increasingly using foreign contents to stimulate their export production.

At the aggregate level, our results show that Taiwan's DVA absorbed in China has increased over time, and a large part of Taiwan's DVA absorbed in China has been via intermediate products and intermediates that are then re-exported to third countries. Our results also reveal an increasing trend of South Korea's DVA absorbed by China's final demand, as well as its domestic and export production. More than 80 percent of South Korea's DVA absorbed in China has been due to intermediate exports. Finally, our results further show that China's export production has increasingly used more value-added sourced from Taiwan and South Korea since 1995.

This paper contributes to the literature of vertical specialization by describing the value chain transition in East Asia's production networks over the last two decades, using the time series world input-output tables from the WIOD. However, WIOD only includes six economies from East Asia while ignoring many other countries located in the same region. The results thus cannot fully reflect the transition in East Asia's value chains, especially in evaluating how other emerging economies in the region have integrated into East Asian production chains. Furthermore, the 35-sector aggregation in the WIOD tables based on 'average' estimates assumes homogeneity of production processes of sub-level industries and products. Thus it underestimates the true foreign contents in exports if exporting firms increase their imports of intermediates (Bernard et al., 2007). Data with additional firm-level information that identifies imports and exports at the firm level provides more accurate measures of value-added and imports embodied in exports (Ahmad and Araujo, 2011). 


\section{References}

Ahmad, N. and S. Araujo, 2011. "Using trade micro data to improve trade in value added measures: Proof of concept using Turkish data", Working Party on International Trade in Goods and Trade in Services Statistics, OECD.

Arndt, S. and H. Kierzkowski(eds.), 2001. "Fragmentation: New Production Patterns in the world Economy". Oxford, UK: Oxford University Press.

Ando, M., 2006. "Fragmentation and vertical intra-industry trade in East Asia", North American Journal of Economics and Finance, 17: pp. 257-281.

Athukorala, P.-C., 2003. "Production Fragmentation and Trade Patterns in East Asia", Working paper No. 2003/21, Research School of Pacific and Asian Studies, Australian National University

Athukorala, P.-C.and N. Yamashita, 2006. "Production Fragmentation and trade integration: East Asia in a global context", North American Journal of Economics and Finance, 17, pp. 233-256.

Balassa, B., 1965. "Trade Liberalization and 'Revealed' Comparative Advantage", Manchester School of Economic and Social Studies, 33, pp. 99-123.

Balassa, B., 1967. "Trade liberalization among industrial countries", McGraw-Hill, New York.

Bernard, A., J. Jensen, S. Redding, and P. Schott, 2007."Firms in International Trade", NBER Working Paper, no. 13054.

Daudin, G., C. Rifflart, and D. Schweisguth, 2010."Who produces for whom in the world economy”, OFCE working paper, Sciences Po Paris, July.

Eurostat, 2011. "High-technology and knowledge-intensive sectors", Available online at http://epp.eurostat.ec.europa.eu/cache/ITY_SDDS/en/htec_esms.htm

Feenstra, R., 1998. "Integration of trade and disintegration of production in the global economy", Journal of Economic Perspectives, 12(4), pp. 31-50. 
Feenstra, R. and J. B. Jensen, 2009. "Evaluating estimates of materials offshoring from U.S.Manufacturing", Paper presented at the National Academy of Public Administration Conference "Measurement Issues Arising from the Growth of Globalization", November 6-7.

Hummels, D., D. Rapoport, and K-M.Yi, 1998."Vertical Specialization and the Changing Nature of World Trade." Federal Reserve Bank of New York Economic Policy Review, pp. 79-99.

Hummels, D., J. Ishii, and K-M.Yi, 2001. "The Nature and Growth of Vertical Specialization in World Trade," Journal of International Economics 54, pp. 75-96.

Ishii, J. and K-M.Yi, 1997.“The Growth of World Trade.” Federal Reserve Bank of New York Research Paper no. 9718, May.

Johnson, C. R. and G. Noguera, 2012a. "Accounting for intermediates: Production sharing and trade in value added", Journal of International Economics, 86, pp. 224-236.

Johnson, C. R. and G. Noguera, 2012b. "Fragmentation and trade in value added over four decades", NBER Working Paper 18186, NBER.

Kan, A. S. and M. W. Morrison, 2014."U.S-Taiwan relationship: overview of policy issues”, Congressional Research Service, 7-5700, R14952.

Kim, J-K., Y. Kim, and C. L. Lee, 2006."Trade, investment and Economic interdependence between South Korea and China”, Asian Economic Journal, 20 (4), pp 379-392.

Kim, W., 2011."Changes in China's influence on South Korean Exports by Production phase", Journal of East Asian Economic Integration, 15 (3), pp. 27-48.

Koopman, R., Z. Wang, and S.-J.Wei, 2008a. "A world factory in global production chains: Estimating imported value added in exports by the People's Republic of China", in Robert Barro and Jong-Wha Lee, eds, Costs and Benefits of Economic Integration in Asia, Oxford University Press.

Koopman, R, Z. Wang, and S.-J.Wei, 2008b. "How much Chinese exports is really made in China - Assessing foreign and domestic value-added in gross exports", NBER Working Paper 14109. 
Koopman, R., W. Powers, Z. Wang and S.-J.Wei, 2010. "Give Credit Where Credit Is Due: Tracing Value Added in Global Production Chains", NBER Working Paper16426.

Koopman, R., Z. Wang, and S.-J.Wei, 2012.“Tracing value-added and double counting in gross exports", NBER Working Paper 18579.

Leamer, E., 2006. "Analyzing the U.S. content of imports and the foreign content of exports", National Research Council, National Academy of Sciences, National Academies Press, Washington, DC.

Leontief, W., 1936. "Quantitative Input and Output Relations in the Economic System of the United States", Review of Economics and Statistics, 18, pp. 105-125.

Linden, G., L. Kenneth, and J. Dedrick, 2007. "What captures value in a global innovation system?”, The Paul Merage School of Business, UC Irvine, working paper.

Masahisa, F., S. Kumagai and K. Nishikimi, 2008.Economic Integration in East Asia -Perspectives from Spatial and Neoclassical Economics, Edward Elgar Publishing.

Miller, R.E. and P.D. Blair, 2009. Input-output Analysis: Foundations and Extensions, Cambridge University Press, Cambridge.

Nanto, D.K., and E. Chanlett-Avery, 2006."The rise of China and its effect on Taiwan, Japan and South Korea: U.S. policy choices”, CRS Report for Congrees, RL 32882.

Nordas, H., 2005. "International production sharing: A case for coherent policy framework", Discussion paper No. 11, World Trade Organization.

OECD, WTO and UNCTAD, 2013. "Implication of global value chains for trade, investment, development and jobs", prepared for G-20 Leaders Summit, September.

Pula, G. and T. Peltonen, 2009. "Has Emerging Asia Decoupled? An analysis ofproduction and trade linkages using the Asian International Input-Output Table", Working paper series, No. 993, European Central Bank, January.

Sturgeon, T., 2010."Mapping global value chains: Intermediate goods trade and structural changes in the world economy", UNIDO working paper 05/2010. 
Timmer, M., A. Erumban, B. Los, R. Stehrer, and G. de Vries, 2013a."Slicing up global value chains", Working Paper 12, World Input Output Database.

Timmer, M., A. Erumban, B. Los, R. Stehrer, and G. de Vries, 2013b."Fragmentation, Incomes and Jobs: An analysis of European competitiveness", European Central Bank Working Paper Series, No.1615.

Timmer, M. (ed.), 2012.“The world input-output database (WIOD): Contents, Source and Methods", WIOD Working paper series, April.

Tuan, C. and F.Y. Ng, 2004. "Manufacturing agglomeration as incentives to Asian FDI in China after WTO”, Journal of Asian Economics, 15, pp. 673-693

Varian, H. R, 2007. "An iPod has global value. Ask the (many) countries that make it", The New York Time, June 28.

Wang, X. and S-J.Wei, 2008. "What account for the rising sophistication of China's exports?”, NBER Working Paper 13771 (February).

Wang, Z, W. Powers and S.-J. Wei, 2009."Value chains in East Asian Production networks - An international input-output model based analysis”, U.S. International Trade Commission Working paper, No. 2009-10-C.

Wang.Z, S.-J.Wei, and K. Zhu, 2013.“Quantifying international production sharing at the bilateral and sector levels", NBER Working Paper Series 19677 (November).

WTO, and IDE-JETRO, 2011. "Trade patterns and global value chains in East Asia: From Trade in Goods to Trade in Tasks", (Geneva, Switzerland, World Trade Organization and Tokyo, Japan,IDE-JETRO).

Xing, Y., 2010. "Facts about and impacts of FDI on China and the world economy", Chin. Int. J. 8 (2), 309-327.

Xu, X. and Y. Gao, 2007. "Export Processing Zones in China: A Survey", A report summited to ILO, October. 
Zhou, J. and M. Latorre, 2014. "How FDI influences the triangular trade pattern among China, East Asia and the U.S.? A CGE analysis of the sector of Electronics in China", Economic Modelling, 44, pp. 577-588.

\section{Appendix}

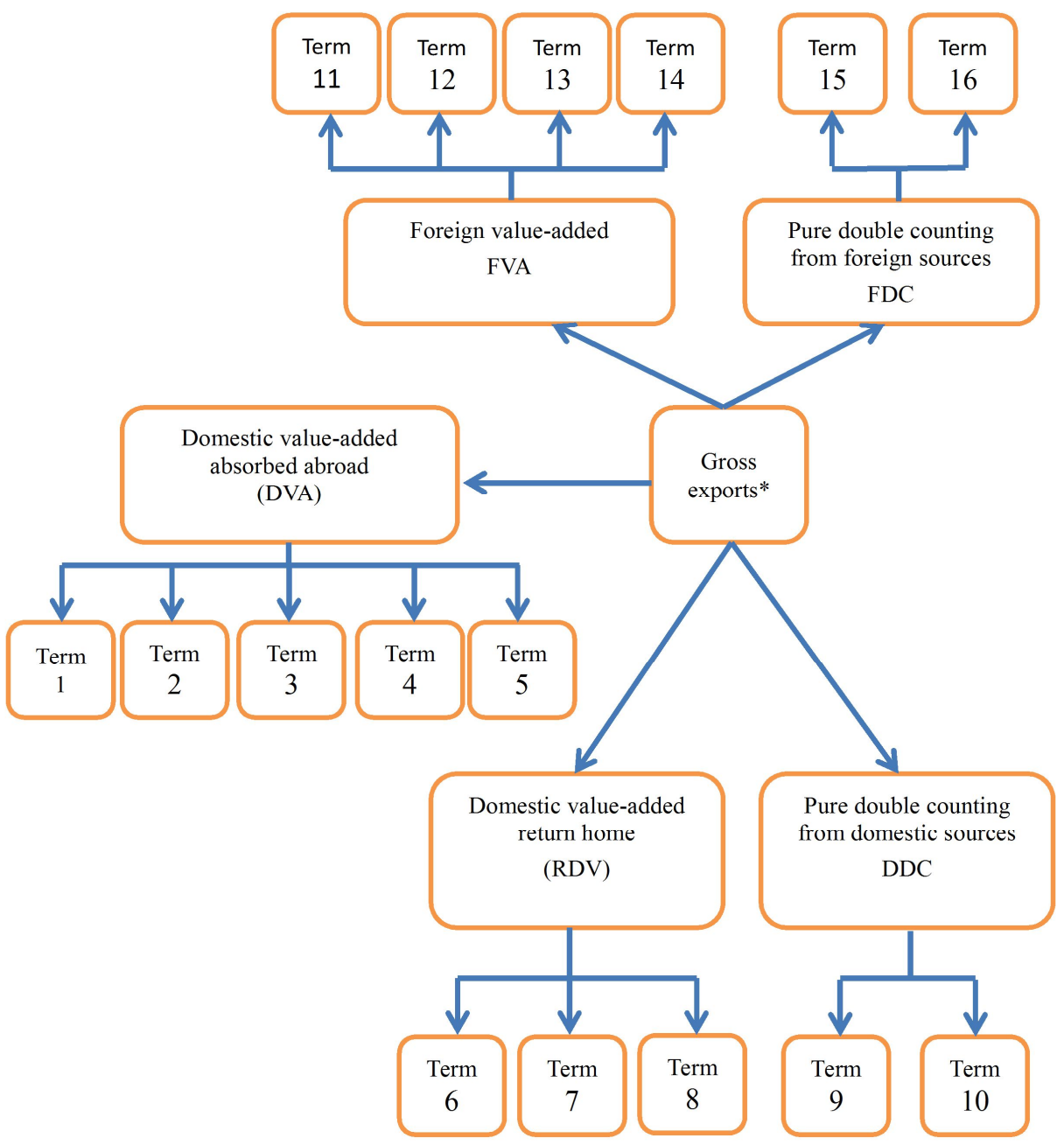

